\title{
Effects of Rare Earth Elements on Bacteria in Rhizosphere, Root, Phyllosphere and Leaf of Soil- Rice Ecosystem
}

\section{Xinzhuan Zhang}

Shangrao Normal University

\section{Zhongjun Hu}

Shangrao Normal University

\section{Huahua Pan}

Shangrao Normal University

\section{Yijun Bai}

Shangrao Normal University

\section{Ying Hu}

Research Center for Eco-Environmental Sciences, Chinese Academy of Sciences

Shulan Jin ( $\nabla$ jsl809@163.com )

Shangrao Normal University

\section{Research Article}

Keywords: earth, bacteria, rhizosphere, root, phyllosphere, leaf, soil-rice ecosystem, rice biomass,

Posted Date: July 13th, 2021

DOI: https://doi.org/10.21203/rs.3.rs-682010/v1

License: (1) This work is licensed under a Creative Commons Attribution 4.0 International License. Read Full License

Version of Record: A version of this preprint was published at Scientific Reports on February 8th, 2022. See the published version at https://doi.org/10.1038/s41598-022-06003-2. 


\title{
Effects of rare earth elements on bacteria in rhizosphere, root,
}

\section{phyllosphere and leaf of soil-rice ecosystem}

\author{
Xinzhuan Zhang ${ }^{1}$, Zhongjun $\mathrm{Hu}^{1}$, Huahua Pan ${ }^{1}$ Yijun Bai ${ }^{1}$, Ying $\mathrm{Hu}^{2}$, Shulan $\mathrm{Jin}^{1}{ }^{\circledR}$ \\ 1.Shangrao Normal University, Shangrao, 334000, China. \\ 2. Research Center for Eco-Environmental Sciences, Chinese Academy of Sciences,Beijing, 100085, China \\ e-mail: js1809@163.com
}

The effects of rare earth mining on rice biomass, rare earth element(REE) content and bacterial community structure was studied by pot experiment. The research showed that the REE content in rice roots, shoots and grains was significantly positive correlated with that in soil, and the dry weight of rice roots, shoots and grains was highly correlated with soil physical and chemical properties, nutrient elements and REE contents; The exploitation of rare earth minerals inhibited a-diversity of endophytic fungi in rhizosphere, root, phyllosphere and leaf of rice, significantly reduced the abundance index, OTU number, Chao, Ace index and also significantly reduced the diversity index-Shannon index and Inv-Simpson index, also reduced uniformity index: Pielou's evenness index, Simpson's evenness index, etc, which caused $\beta$-diversity of bacteria to be quite different. The exploitation of rare earth minerals reduces the diversity of bacteria, but forms dominant bacteria, such as Burkholderia, Bacillus, Buttiauxella, Acinetobacter, Bradyrhizobium, Candida koribacter, which can degrade the pollutants formed by exploitation of rare earth minerals, alleviate the compound pollution of rare earth and ammonia nitrogen, and also has the function of fixing nitrogen and resisting rare earth stress; The content of soil available phosphorus in non mining area is low, forming the dominant bacteria of Pantoea, which has the function of improving soil phosphorus availability. Rare earth elements and physical and chemical properties of soil affect the community structure of bacteria in rhizosphere and phyllosphere of rice, promote the parallel movement of some bacteria in rhizosphere, root, phyllosphere and leaf of rice, promote the construction of community structure of bacteria in rhizosphere and phyllosphere of rice, give full play to the growth promoting function of Endophytes, and promote the growth of rice. The results showed that the rice biomass in mining area was guaranteed due to the growth promoting effect of endophytic bacteria, However, the mining of mineral resources causes the compound pollution of rare earth and ammonia nitrogen, which makes REE content of rice in mining area significantly higher than that in non mining area.

China is a world power in the production, export and consumption of rare earth resources. China has about 50 percent of the world's rare earth resources and provides about 90 percent of the global supply of rare earth according to reports ${ }^{1}$. The southern China, which is centered on Ganzhou City, Jiangxi Province, is an important distribution area of ion-type rare earth resources in the world, and its reserves account for about $70 \%$ of the world ${ }^{2}$. The southern China is not only rich in ion rare earth resources, but also an important rice production area in the world. Illegal and disorderly exploitation of rare earth resources caused large amount of of rare earth elements to enter the soil and water environment, which affects the growth of plants, animals and 
microorganisms in the environment, thus changes the ecological environment and affects human health ${ }^{3-4}$ through the food chain. Rice is the main grain in southern China, and the yield and quality of rice are closely related to the ecological environment of farmland. Microorganism is the most sensitive indicator of farmland ecological environment. The microorganism is affected by climate factors, soil physical and chemical properties, plant species/genotypes, and also affected by heavy metal pollution ${ }^{5-6}$

With the extensive use of rare earth resources in many industries, the world's demand for rare earth resources increased from 136,000 $\mathrm{t}$ in 2017 to $151,000 \mathrm{t}$ in $2020^{7}$. The increasing demand promotes the development and processing of rare earth. The impact of rare earth development and smelting on the environment has attracted much attention. It is reported that the REE content in soil of rare earth mining area in South China is $396-2314 \mathrm{mg} / \mathrm{kg}^{8}$, which is much higher than the average REE content in soil of China. The concentration of rare earth in water is 1000 times $^{9}$ higher than that of ordinary fresh water. Rare earth elements in ecosystems not only affect plants and animals, but also affect the growth, development, reproduction, migration and colonization of microorganisms ${ }^{10-11}$. Rare earth elements affect the growth indexes of plants, including the biomass of aboveground and underground parts. It affects the index of plant resistance system, such as plant enzyme activity, etc. It also affect the REE content in plants ${ }^{12-13}$. The effect of rare earth elements on microorganisms is significant. The appropriate concentration of rare earth elements can promote the growth and reproduction of bacteria and the increase of metabolites. High concentration of rare earth can inhibit microorganism ${ }^{14}$. Chu Haiyan et al. ${ }^{15}$ found that $\mathrm{La}^{3+}$ has strong toxic effect on bacteria, actinomycetes, fungi and other microorganisms in the red soil microflora. He Qizhuang et al. ${ }^{16}$ found that rare earth elements had strong inhibitory effect on Escherichia coli, Staphylococcus aureus and Candida albicans. The research of Wang Yousheng et al. ${ }^{17}$ showed that the changes of soil REE content and physical and chemical properties significantly affected the diversity and abundance of soil bacteria. The research of Wang Jianhong ${ }^{18}$ showed that the microbial biomass in the areas with serious accumulation of rare earth was inhibited, the bacterial diversity in the non rare earth mining area was higher than that in the mining area, and the species were relatively rich. The REE content is the main factor affecting the microbial structure. Rare earth elements are very important for methoxybacteria in extremely acidic environment. ${ }^{19-21}$

After rare earth elements enter the soil, on one hand, they directly affect the microorganisms in the soil-plant ecosystem, on the other hand, they indirectly affect the microorganisms by influencing the physical and chemical properties of the soil and the plant biochemical system, while the microorganisms react on the soil and plants, and affect the migration and transformation of rare earth elements in soil and plant. Microorganisms in soil are oxidized, nitrated, ammoniated, nitrogen fixation and vulcanization, which promote the decomposition of soil organic matter and nutrient transformation. Endophytes have significant effects on plants, e.g. endophytic bacteria have nitrogen fixation effect on rice. The common endophytic azotobacters are Pseudomonas, Spirulina, Enterobacteriaceae and Bacillus to reduce the free N2 in the atmosphere into the available $\mathrm{NH}_{4}{ }^{+}$by nitrogenase ${ }^{22-23}$. The endogenous bacteria can secrete indoleacetic acid, which can promote the cell elongation, cell division and root growth of plants, assist host rice to improve the absorption efficiency of N, P and K, improve the production of gibberellin and salicylic acid in rice, and inhibit the production of jasmonate and abscisic acid to promote rice growth ${ }^{24-26}$. Endophytic bacteria can help to resist sheath blight, and the effect of disease resistance is better 
than that of chemical fungicides. The mechanism of rice endophytes assisting host rice disease resistance mainly includes secretion of antibiotics, hyperparasitism, niche competition and induction of rice self-resistance ${ }^{27-28}$. To resist abiotic stress, endophytic bacteria can help heavy metal contaminated plants to carry out bioremediation, e.g. Zhou et al. ${ }^{29}$ found that endophytic bacteria Stenotrophomonas maltophilia R5-5 significantly reduced the cadmium content in rice plants by down regulating the gene expression of cadmium absorption and transport proteins in rice and changing the community structure of endophytic bacteria. Endophytic bacteria can increase the biomass yield of host plants under different heavy metal stress, which indicates thatEndophytic bacteria can effectively protect plants from the toxicity of many heavy metals $(\mathrm{Cd}$, $\mathrm{Cu}, \mathrm{Cr}, \mathrm{Mn}, \mathrm{Ni}, \mathrm{Pb}$ and $\mathrm{Zn}){ }^{30}$

At present, the research on the effect of endophytes on rice is mainly carried out in non polluted habitats, but the research on heavy metal polluted habitats is relatively lacking, and the research on rare earth polluted habitats has not been reported. In this study, the soil of typical REE mining area in Ganzhou City of Jiangxi Province was taken as the research object, and the soil of non mining area was taken as the control check (CK). The effects of rare earth elements on bacteria in rhizosphere, root, phyllosphere and leaf of soil rice ecosystem were discussed, which has scientific research value and practical significance.

\section{Results}

Effects of mineral exploitation on soil physical and chemical properties, REE content, rice biomass and REE content.

It can be seen from table 1 that the contents of rare earth elements, ammonia nitrogen, nitrate nitrogen, total $\mathrm{P}$ and available $\mathrm{P}$ in soil of $\mathrm{H}$ and $\mathrm{M}$ at both tillering stage and maturity stage of rice are significantly higher than those of $\mathrm{L}$, and the $\mathrm{pH}$ value is lower than that of $\mathrm{L}$. The results show that both $\mathrm{H}$ and $\mathrm{M}$ are soil samples in the mining area, and the mining of rare earth minerals can significantly improve the REE content in soil and affect the physical and chemical properties of soil.

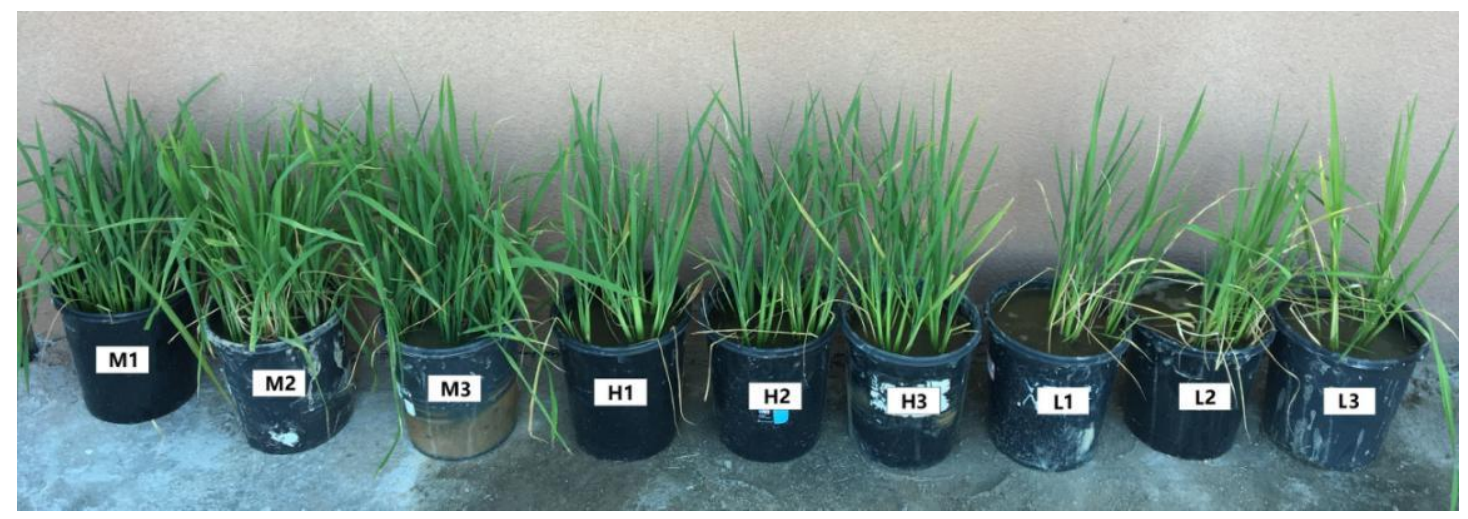

\section{Figure 1 Growth of rice at tillering stage}

It can be seen from Fig. 1 that the tillering shoots of rice cultivated in soil $\mathrm{M}$ are the most at tillering stage, and the rice is dense and growing well; The rice cultivated in $\mathrm{H}$ soil has more tillers and leaves, which is more dense and grows better; The tillering shoots of rice cultivated in L soil were less and the growth vigor was general. It can be seen from Fig. 2 that the weight of root, shoot and grain of rice in soil $\mathrm{M}$ is the largest, with an average of $38.9 \mathrm{~g}, 93.8 \mathrm{~g}$ and $123.8 \mathrm{~g}$ respectively, followed by $\mathrm{H}$, with an average of $33.7 \mathrm{~g}, 84.7 \mathrm{~g}$ and $103.7 \mathrm{~g}$ respectively, and then $\mathrm{L}$, with an average of $22.8 \mathrm{~g}, 52.1 \mathrm{~g}$ and $63.7 \mathrm{~g}$ respectively. The weight of root, shoot and grain of $\mathrm{M}$ 
was $1.15,1.11$ and 1.19 times of $\mathrm{H}$, and $1.71,1.80$ and 1.94 times of $\mathrm{L}$, respectively.
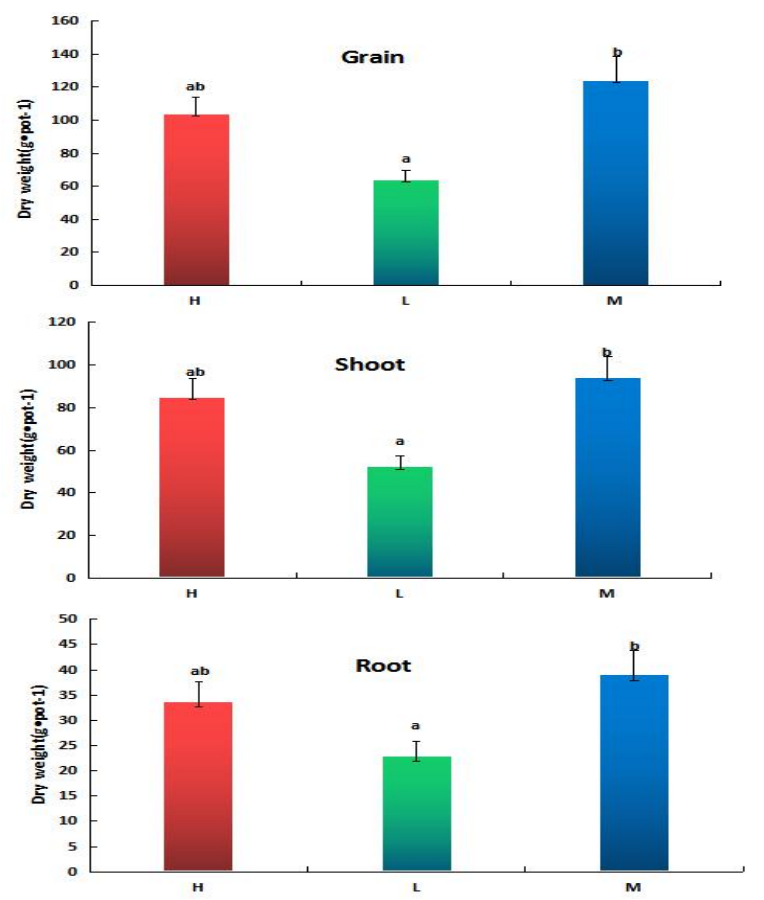

Figure 2 Dry weight of grain, shoot and root of rice

Different letters indicate significant differences between potted rice in different soils
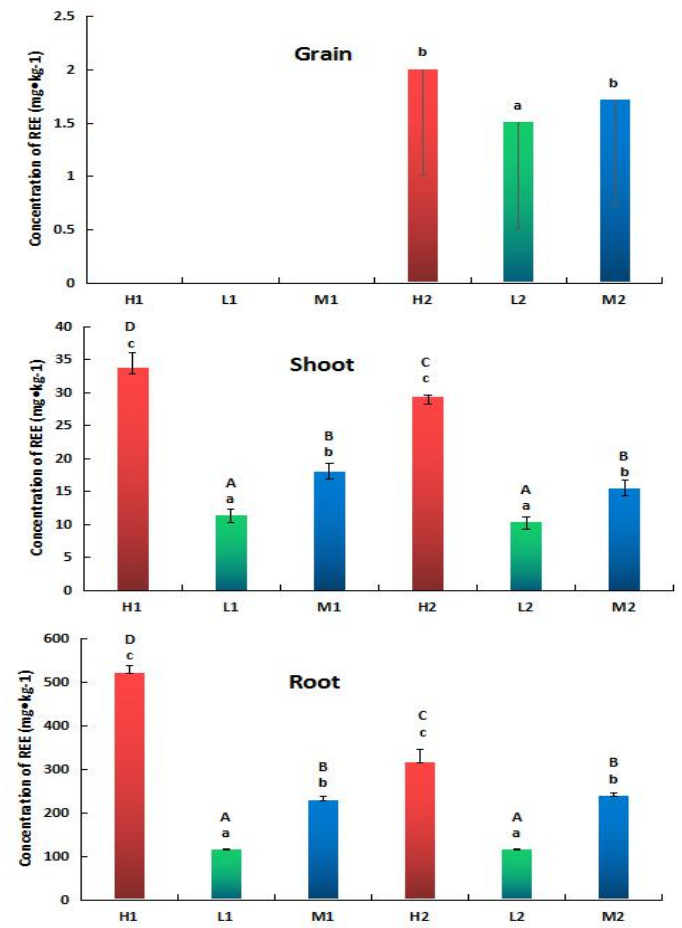

Figure 3 Content of rare earth elements in shoots and roots of rice at tillering stage and grains, shoots and roots at maturity stage

Different letters indicate significant differences between pot experiment rice in different soil (lowercase letters indicate significant differences in the same stage, capital letters indicate significant differences between the two stages), $\mathrm{P}<0.05$ 
It can be seen from Fig. 3 that the REE contents in different parts of rice at tillering stage and maturity stage are significantly positively correlated with the REE contents in soil. The REE contents in roots, shoots and grains of rice cultured in soil of $\mathrm{H}$ were the highest, followed by $\mathrm{M}$, and $\mathrm{L}$ was the lowest. At tillering stage, the REE content in rice roots, shoots of $\mathrm{H}$ were 2.28 and 1.89 times that of $\mathrm{M}, 4.53$ and 2.98 times that of L, respectively. At maturity stage, the REE content in rice roots, shoots and grains of $\mathrm{H}$ were 1.32, 1.91 and 1.17 times that of $\mathrm{M}$, and 2.76, 2.83 and 1.33 times of $\mathrm{L}$, respectively.

Effects of soil REE content and physicochemical properties on microbial diversity in rhizosphere, root, phyllosphere and leaf of rice.

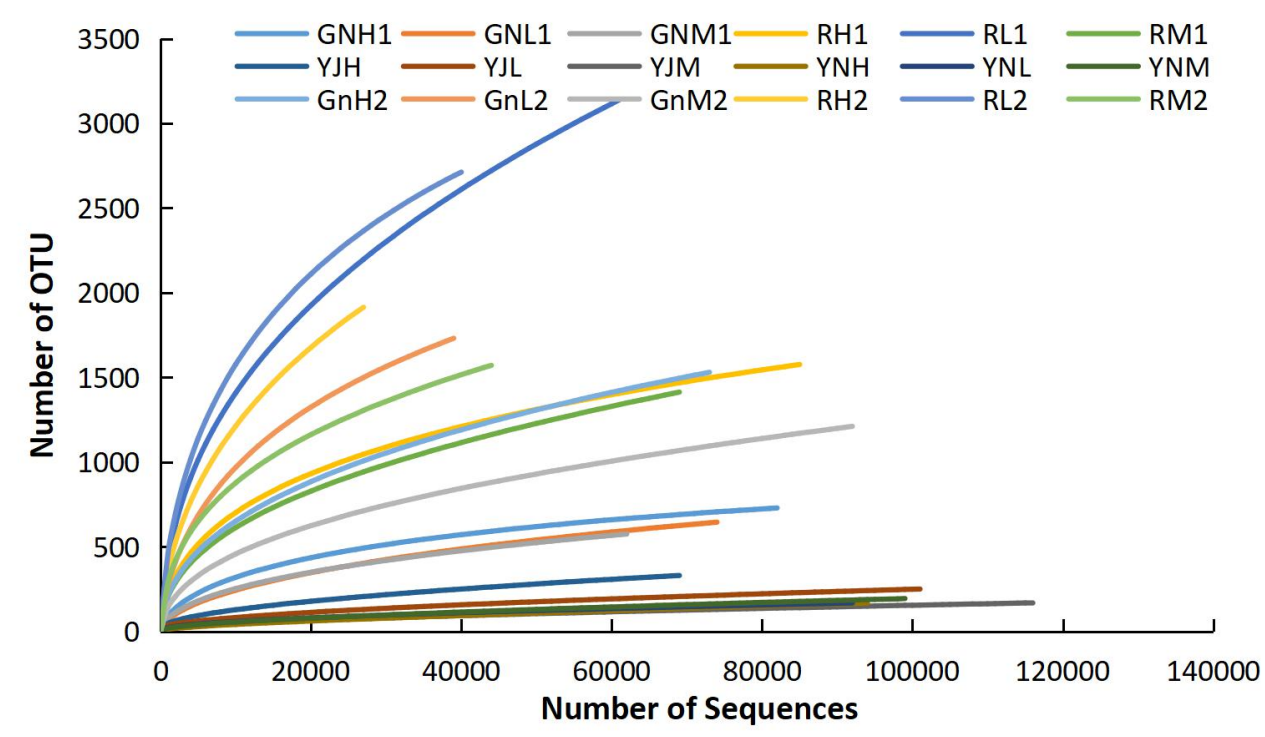

Figure 4 Dilution curve of bacterial $16 \mathrm{~S}$ gene sequence

Effect of soil rare earth elements on bacteria $\alpha$-diversity, including abundance index: OTU number, Chao, Ace; Diversity index: Shannon Weiner index, Simpson's diversity index; Evenness index: Pielou's evenness index, etc. GN (H1, M1, L1), R (H1, M1, L1), YJ (H, M, L) and YN (H, M, L) in Fig. 4 respectively represent the bacteria in the root, rhizosphere, phyllosphere and leaf of rice at tillering stage, $\mathrm{GN}(\mathrm{H} 2, \mathrm{M} 2, \mathrm{~L} 2)$ and $\mathrm{R}(\mathrm{H} 2, \mathrm{M} 2, \mathrm{~L} 2)$ respectively represent the bacteria in the root and rhizosphere of rice at maturity stage, the same below. As can be seen from the Fig.4 that the number of OTU is affected by soil rare earth elements. The number of OTU in rhizosphere, root, phyllosphere and leaf of rice cultivated in soil of $\mathrm{H}$ and $\mathrm{M}$ of rare earth mining area is mostly lower than that of rice cultivated in soil $\mathrm{L}$ of non rare earth mining area. At tillering stage, the difference of OTU number among three different soil cultures was the largest. The OTU number of L sample on the same band number was the largest, followed by $\mathrm{H}$, and the smallest was $\mathrm{M}$. when the number of sequencing bands was 61,000 , the OTU number of L sample was 2.23 and 2.34 times that of $\mathrm{H}$ and $\mathrm{M}$, respectively. The OTU number of rhizosphere bacteria in $\mathrm{L}$ sample was the largest, followed by $\mathrm{H}$ and $\mathrm{M}$. when the number of sequencing bands was 27,000 , the OTU number of rhizosphere bacteria in L sample was 1.24 and 1.81 times that of $\mathrm{H}$ and $\mathrm{M}$ respectively. When the number of sequencing bands was 39,000, the OTU number of rhizosphere bacteria in $\mathrm{L}$ sample was 1.47 and 2.07 times that of $\mathrm{H}$ and $\mathrm{M}$ respectively.

As can be seen from the Fig. 5 that the Shannon index of rhizosphere, root, phyllosphere and leaf of rice cultivated by $\mathrm{H}$ and $\mathrm{M}$ in mining area was lower than that of $\mathrm{L}$ in non mining area, 
especially the Shannon index of rhizosphere and endophyllum of rice cultivated by $\mathrm{H}$ and $\mathrm{M}$ in tillering stage was significantly lower than that of $\mathrm{L}$, which were 0.55 and 0.61 times that of $\mathrm{L}$, respectively. The Simpson's evenness index of rhizosphere, root, phyllosphere and leaf in tillering stage and maturity stage of rice was affected by rare earth mining. The Simpson's evenness index of rhizosphere bacteria in $\mathrm{H}$ and $\mathrm{M}$ groups was 0.62 and 0.44 times higher than that of $\mathrm{L}$ in tillering stage, The Simpson's evenness index of M group was 0.44 times that of $\mathrm{L}$ and $\mathrm{H}$. The Chao1 index of rhizosphere, root, phyllosphere bacteria in M group was lower than that in L group at tillering stage and maturity stage, and the significant difference was that the bacteria in rhizosphere and root at tillering stage were $0.53,0.46,0.52$ and 0.48 times that in L group, respectively. The richness of most samples in group $\mathrm{H}$ and $\mathrm{M}$ was lower than that in group $\mathrm{L}$. the richness of rhizosphere and endophytic bacteria in group $\mathrm{H}$ and $\mathrm{M}$ was significantly lower than that in group $\mathrm{L}$ at tillering stage and maturity stage, which were $0.54,0.42,0.72,0.43,0.74,0.52$, 0.65 and 0.48 times that in group L, respectively. The inv-Simpson of rhizosphere bacteria in group $\mathrm{H}$ and $\mathrm{M}$ was significantly lower than that in group $\mathrm{L}(0.34,0.18,0.44$ and 0.18 times of that in group L), while inv-Simpson of rhizosphere bacteria in group $\mathrm{M}$ was significantly lower than that in group L ( 0.32 and 0.20 times of that in group L). Mining reduced the Pielou's evenness index of bacteria, and the most important factor was the leaf bacteria at tillering stage. The index of $\mathrm{H}$ and $\mathrm{M}$ groups was only 0.56 and 0.67 times of $\mathrm{L}$, respectively. 

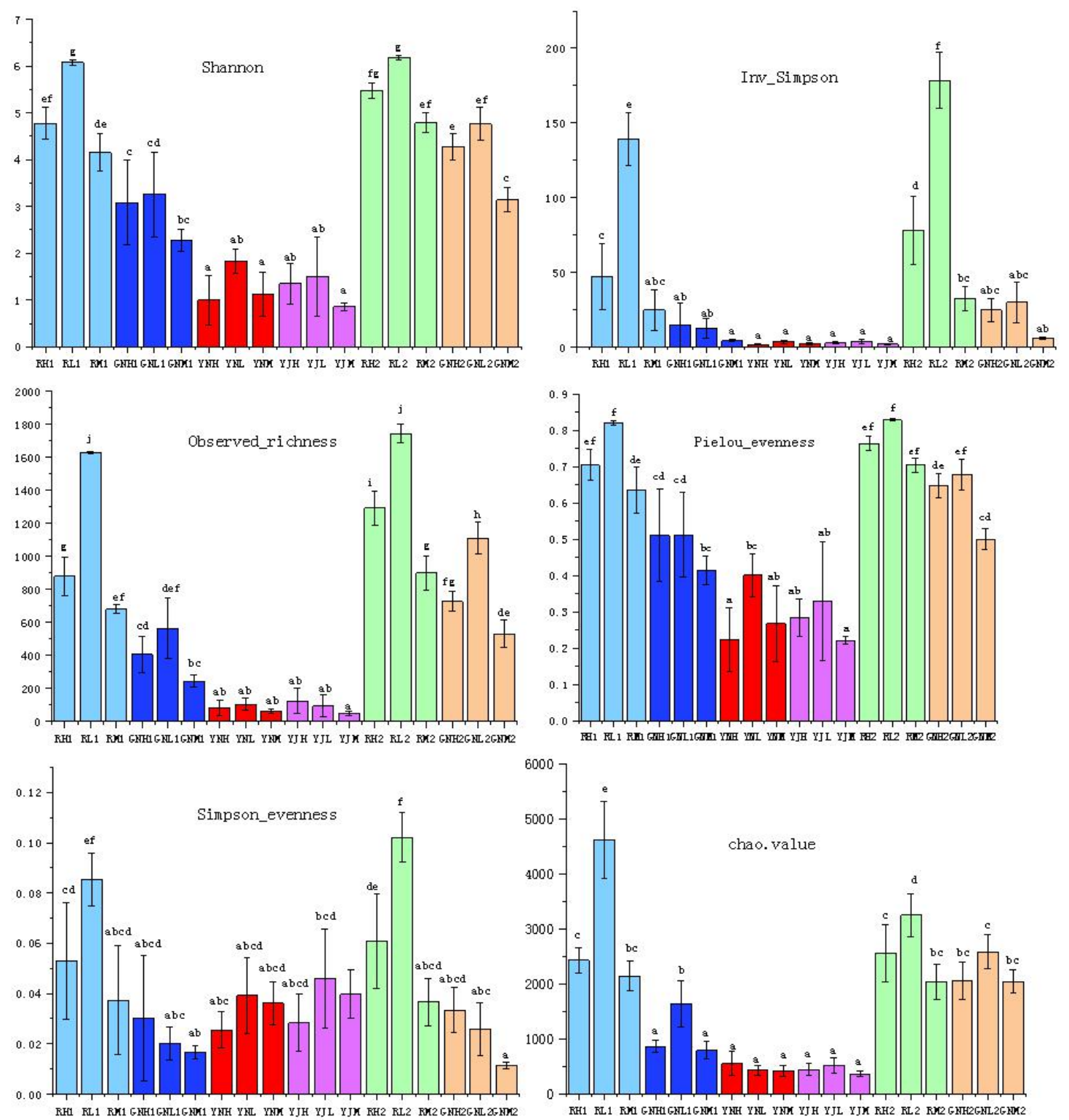

Figure $5 \alpha$-diversity of bacteria in root, rhizosphere, leaf and phyllosphere of rice at tillering and maturity stages

Notes:Different letters indicate the significant difference among bacteria of different soil pot-experiment rice (small letters indicate the significant difference in the same stage, capital letters indicate the significant difference between the two stages), $\mathrm{P}<0.05$ 

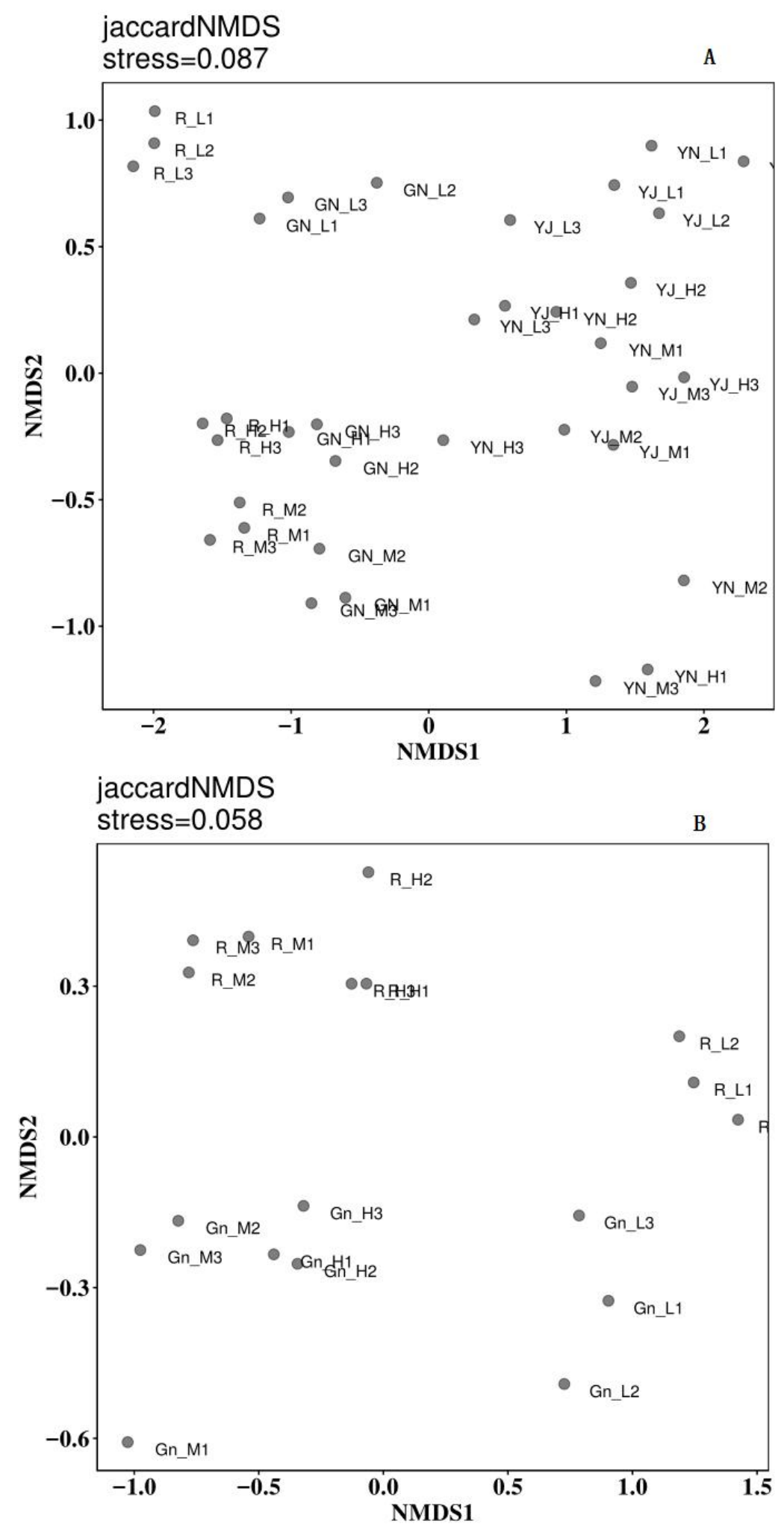

Figure 6 -diversity of bacterial community structure of pot-experiment rice in different soils based on NMDS analysis

$\mathrm{A}$ and $\mathrm{B}$ are the results of NMDS analysis at tillering stage and maturity stage respectively in Figure 6. It can be seen from Figure 6 that the bacteria in different parts of rice cultivated in the same soil have a greater degree of dispersion, that is, the bacteria in rhizosphere, root, phyllosphere and leaf are dispersed in both tillering stage and maturity stage; The bacteria in the 
same part of rice cultivated in soils with different REE contents were also dispersed, especially the difference between $\mathrm{H}$ and $\mathrm{M}$ in mining area and 1 in non mining area was larger. In Fig. 6, the stress values of $A$ and $B$ are 0.087 and 0.058 , respectively, which are less than 0.1 , indicating that the difference of NMDS Bray Curtis is significant. The effect of rare earth mining on $\beta$-diversity of bacteria is obvious.

Effects of soil REE content and physicochemical properties on bacterial community structure in rhizosphere, root, phyllosphere and leaf of rice

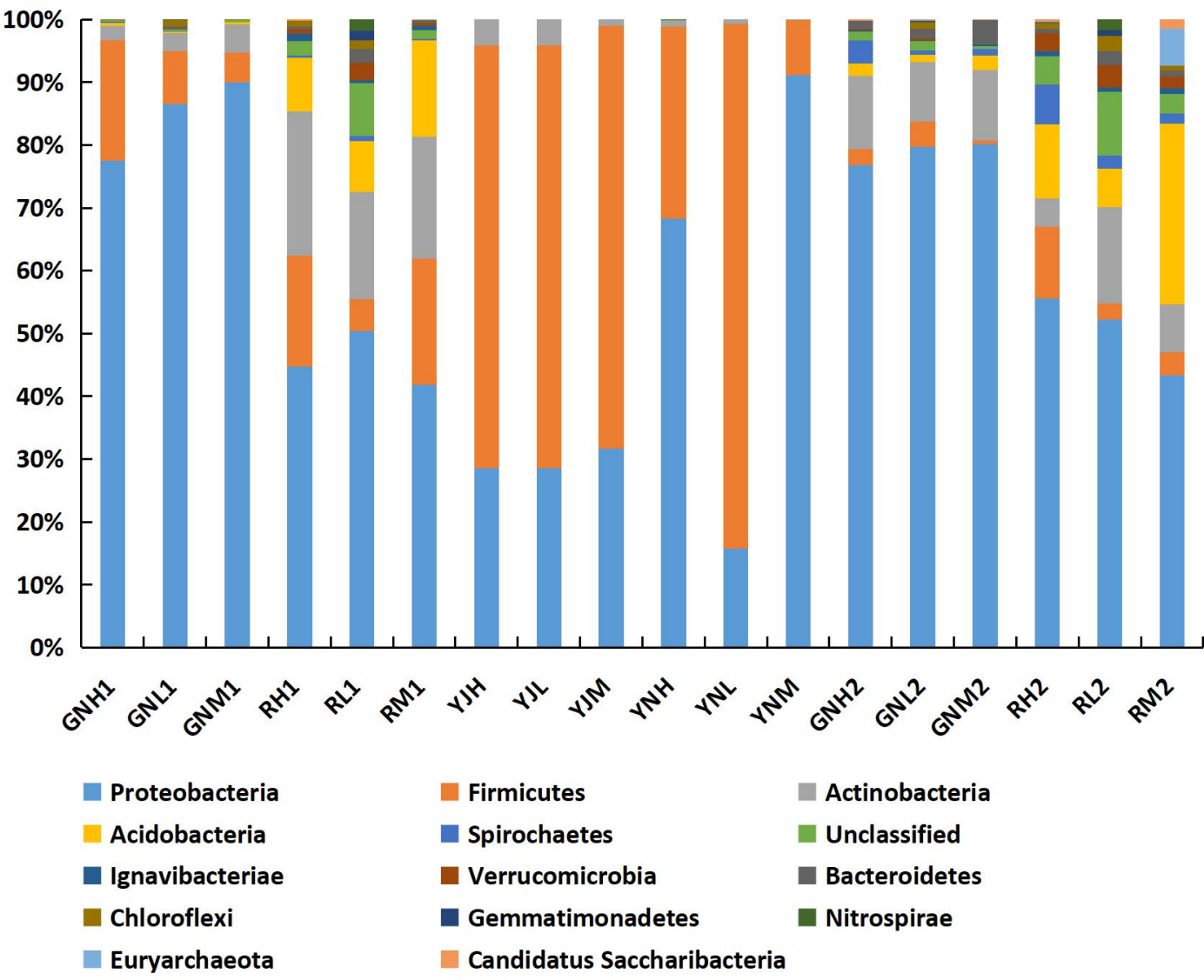

Figure 7 Bar chart of the phylum level

It can be seen from Fig.7 that there are Proteobacteria, Firmicutes, Actinobacteria, acidobacteria, etc. in rhizosphere, root, phyllosphere and leaf of rice at tillering stage and in rhizosphere, root of rice at maturity stage. Exploitation of rare earth mining has significant effect on Proteobacteria of rice at tillering stage. The relative abundance of this phyla in group $\mathrm{H}$ and $\mathrm{M}$ is much higher than that in $\mathrm{L}$, which is 4.33 and 5.77 times that in $\mathrm{L}$, respectively; The relative abundance of Firmicutes in rhizosphere of $\mathrm{H}$ and $\mathrm{M}$ groups was significantly higher than that of $\mathrm{L}$ at tillering stage, and the number of bacteria in leaves was significantly lower than that of $\mathrm{L}$. the former was 3.47 and 3.95 times of $\mathrm{L}$, and the latter was 0.37 and 0.11 times that of $\mathrm{L}$, respectively; The relative abundance of $\mathrm{H}$ and $\mathrm{M}$ was 0.61 and 0.14 times higher than that of $\mathrm{L}$, respectively; The relative abundance of $\mathrm{H}$ and $\mathrm{m}$ was 4.40 and 1.44 times higher than that of $\mathrm{L}$, respectively. The relative abundance of Actinobacteria in rhizosphere of group $\mathrm{H}$ and $\mathrm{M}$ was 0.29 and 0.50 times that of group L, respectively. The relative abundance of Actinobacteria in rhizosphere and root of group $\mathrm{H}$ and $\mathrm{M}$ was 1.81 and 2.15 times that of group $\mathrm{L}$, and 1.88 and 4.62 times that of 
group L, respectively.

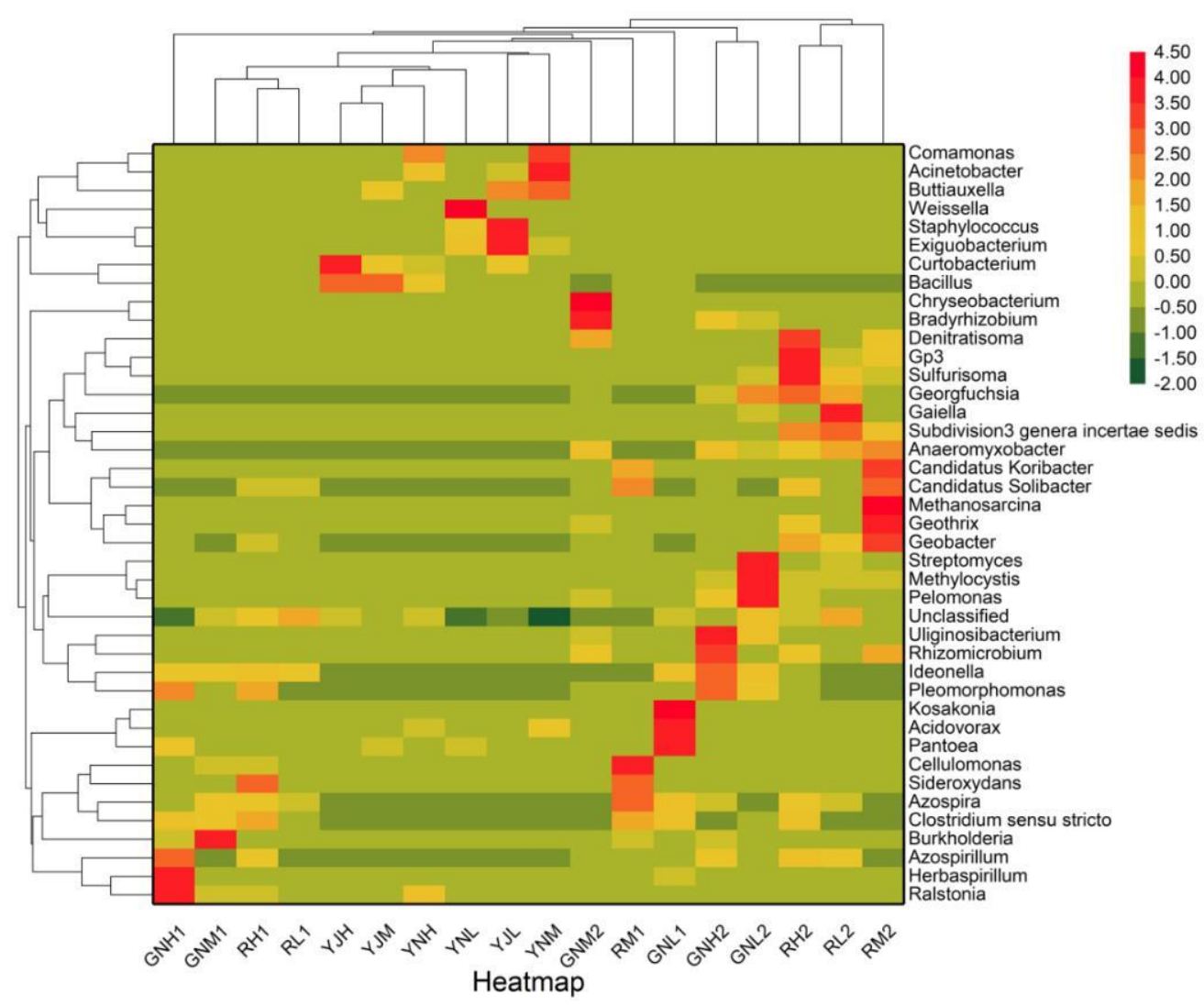

Figure 8 Heatmap of genus level

As can be seen from Fig. 8 that the exploitation of rare earth significantly increased the relative abundance of Ralstonia and Burkholderia in rice roots at tillering stage, and decreased the relative abundance of Pantoea, Acidovorax, Azospira, Buttiauxella and Kosakonia in roots. The relative abundance of Ralstonia in roots of $\mathrm{H}$ and $\mathrm{M}$ groups was 63.42 and 7.5 times that of $\mathrm{L}$, and the relative abundance of Pantoea in roots of L group was 3.29 and 8474 times that of $\mathrm{H}$ and $\mathrm{M}$ group, respectively. The relative abundances of Burkholderia in $\mathrm{M}$ group were 9.23 and 87.71 times higher than those in L group, respectively. The relative abundances of Bacillus, Clostridium sensu stricto, Azospira, Sideroxydans, Cellulomonas and Candida solibacter in rice rhizosphere increased, and the relative abundances of Bacillus and Pantoea in rice phyllosphere also increased, while the relative abundances of Exiguobacterium, Buttiauxella, Acinetobacter and Staphylococcus decreased. The relative abundance of Bacillus in group M was 8.01 and 8.28 times of that in group L, respectively. The relative abundance of Exiguobacterium and Buttiauxella in group L was 44.41, 194.48, 100.83 and 2.11 times of that in group $\mathrm{H}$ and $\mathrm{M}$, respectively. The relative abundance of Acinetobacter and Comamonas in leaves increased, and the relative abundance of Pantoea, Exiguobacterium, Staphylococcus and Weissella in group L decreased The relative abundances of Pantoea, Exiguobacterium, Weissella and Staphylococcus in leaves of group L were 4.72, 55.03, 61.81, 2.88, 45.93, 454.58, 33.00 and 31.43 times of those in leaves of group $\mathrm{H}$ and $\mathrm{M}$, respectively. In addition, Herbaspirillum in roots of group $\mathrm{H}$ was significantly higher than that in roots of group $L$ at tillering stage, which was 7.08 times of that in roots of group L, Bacillus in leaves of group $\mathrm{H}$ was significantly higher than that in leaves of group L, 
which was 3.61 times of that in leaves of group L, and Buttiauxella in group M was significantly higher than that of group L, which was 15.14 times that of group L.

As can be seen from Fig. 8 that the relative abundances of Bradyrhizobium, Burkholderia and Anaeromyxobacter in rice roots at maturity stage significantly increased due to the exploitation of rare earth, while the relative abundances of Georgfuchsia, Pelomonas, Methylocystis, Streptomyces and Methylosinus decreased significantly. The relative abundances of Bradyrhizobium in $\mathrm{H}$ and $\mathrm{M}$ groups were 3017 and 11.89 times that of $\mathrm{L}$, respectively. The relative abundance of Methylosinus was 5.24, 11.66, 6.20 and 6.34 times that of $\mathrm{H}$ and M, respectively. The relative abundance of Bradyrhizobium, Burkholderia, Geobacter, Denitisoma and Candidatus Koribacter in rhizosphere increased, while that of Gaiella decreased. The relative abundance of Geobacter, Candidatus koribacter and Candidatus solibacter in rhizosphere of $\mathrm{H}$ and $\mathrm{M}$ was 1.73 , $2.68,3.57$ and 64.18 times that of L, respectively, The relative abundance of gaiella in rhizosphere of group L was 601.5 and 601.5 times that of $\mathrm{H}$ and $\mathrm{M}$, respectively.

Environmental factors affecting bacterial community of rhizosphere, root, phyllosphere and leaf in soil
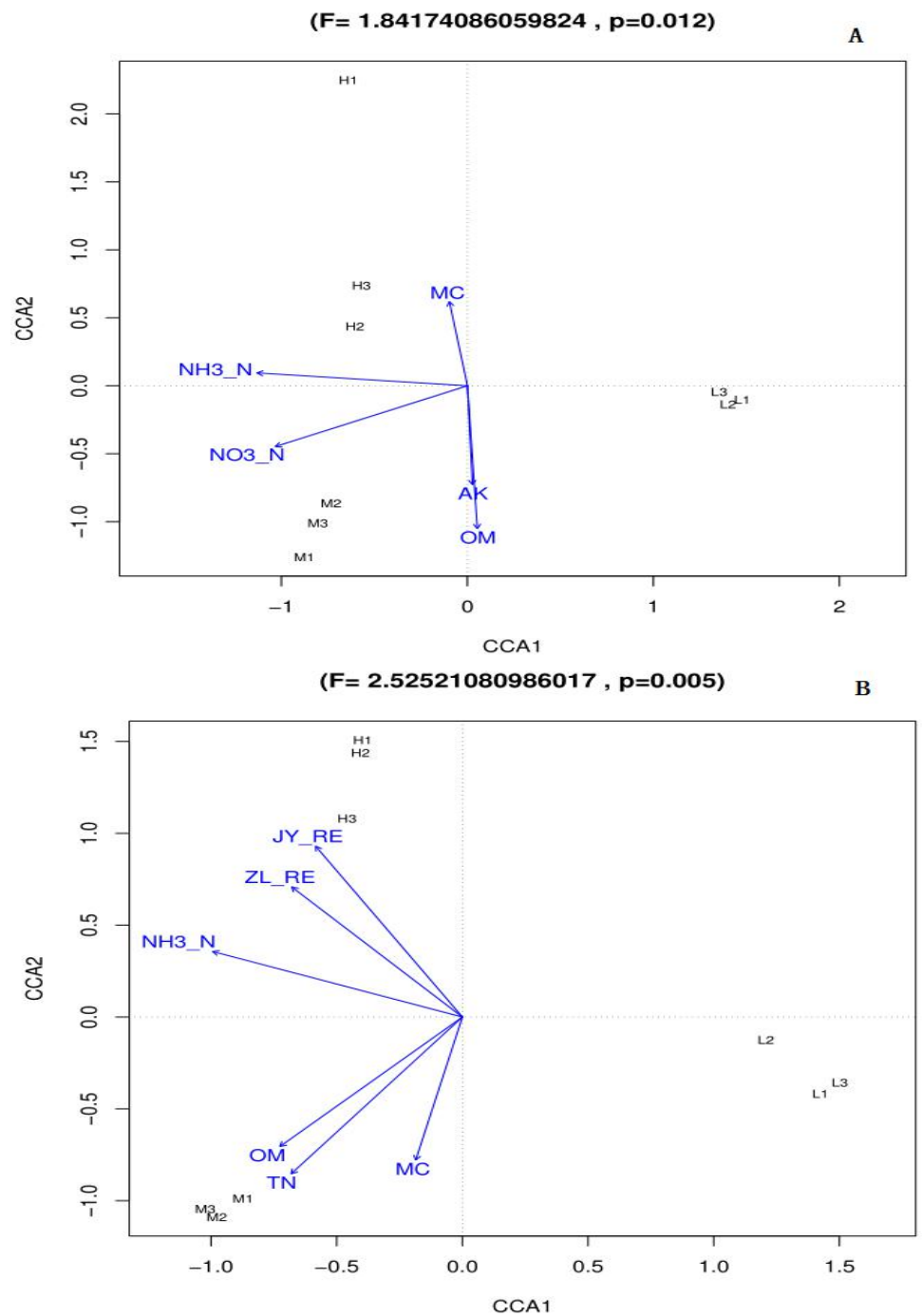

Figure 9 Canonical Correspondence Analysis (CCA) and variation partition analysis (VPA) of rice bacterial community

The bacterial community structure and construction process were affected by environmental 
factors. The relationship between bacterial community and environmental factors was analyzed by CCA. The results are shown in Fig. 9. Due to the differences in REE content and physicochemical properties of soil samples, each group of samples is obviously separated. Fig. 9A shows the environmental factors affecting the three groups of samples in $\mathrm{H}, \mathrm{M}$ and $\mathrm{L}$ at the tillering stage of rice. It can be seen from the figure that the main environmental factors are ammonia $\mathrm{N}$, nitrate $\mathrm{N}$, organic matter and available $\mathrm{K}$.

Fig. $9 \mathrm{~b}$ shows the environmental factors affecting the three groups of samples $\mathrm{H}, \mathrm{M}$ and $\mathrm{L}$ at the maturity stage of rice. It can be seen from the figure that the main environmental factors are the contents of rare earth elements in shoots, grains, ammonia nitrogen, organic matter and total nitrogen. According to Table 1, we can see that Shannon, Inv_Simpson, Richness, Pielou evenness of rice bacteria in rhizosphere, root, phyllosphere and leaf at tillering stage were significantly negatively correlated, highly negatively correlated or negatively correlated with REE content, total $\mathrm{N}$, ammonia $\mathrm{N}$, nitrate $\mathrm{N}$, total $\mathrm{P}$ and available $\mathrm{P}$ in soil, rice roots, shoots, and highly positively correlated with $\mathrm{pH}$. Simpson evenness was significantly negatively correlated with REE contents in rice roots, shoots, negatively correlated with REE contents in soil, ammonia and nitrogen; and positively correlated with available $\mathrm{K}$, organic matter and $\mathrm{pH}$. Chao. value was highly positively correlated with REE contents in roots, shoots of rice, and positively correlated with available $\mathrm{K}$, organic matter and $\mathrm{pH}$. As can be seen from Table 2 that the REE content in soil, rice roots, shoots, grains and soil physical and chemical properties are negatively correlated with the diversity, richness and evenness of bacteria in rhizosphere, root, phyllosphere and leaf at maturity period of rice, and significantly or highly negatively correlated with REE contents, ammonia $\mathrm{N}$, nitrate $\mathrm{N}$ and $\mathrm{pH}$ in soil. As can be seen from Table 3 that the dry weight of rice roots, shoots, and grains are positively correlated with REE content, total $\mathrm{N}$, ammonia $\mathrm{N}$, nitrate $\mathrm{N}$, total $\mathrm{P}$, available $\mathrm{P}$, available $\mathrm{K}$, and organic matter in soil, rice roots, shoots, and negatively correlated with $\mathrm{pH}$.

Table 1 Pearson correlation of rare earth element content, soil physical and chemical properties and $\alpha$-diversity of rice bacteria at tillering stage

\begin{tabular}{lllllll}
\hline & Shanno & $\begin{array}{l}\text { Inv_ } \\
\text { Simpson }\end{array}$ & $\begin{array}{l}\text { Observed_ } \\
\text { richness }\end{array}$ & $\begin{array}{l}\text { Pielou_ } \\
\text { evenness }\end{array}$ & $\begin{array}{l}\text { Simpson_ } \\
\text { evenness }\end{array}$ & chao.value \\
\hline Soil REE content & $-1.000^{*}$ & -0.981 & -0.812 & -0.991 & -0.751 & 0.521 \\
Root REE content & -0.806 & -0.893 & -0.28 & -0.865 & $-.998^{*}$ & 0.936 \\
Shoot REE content & -0.815 & -0.899 & -0.294 & -0.872 & $-.997^{*}$ & 0.931 \\
Total N & -0.327 & -0.166 & -0.834 & -0.224 & 0.35 & -0.613 \\
ammonia N & -0.987 & -0.946 & -0.882 & -0.964 & -0.657 & 0.404 \\
nitrate nitrogen & -0.794 & -0.683 & $-1.000^{* *}$ & -0.724 & -0.225 & -0.075 \\
Total P & -0.559 & -0.415 & -0.948 & -0.467 & 0.097 & -0.388 \\
available P & -0.47 & -0.318 & -0.91 & -0.373 & 0.2 & -0.482 \\
available K & 0.261 & 0.417 & -0.38 & 0.363 & 0.816 & -0.951 \\
organic matter & 0.272 & 0.427 & -0.369 & 0.374 & 0.823 & -0.955 \\
pH & 0.949 & 0.883 & 0.945 & 0.909 & 0.53 & -0.254 \\
\hline
\end{tabular}

** At 0.01 level (two tailed), the correlation was significant, *. At 0.05 level (two tailed), the correlation was significant, $\mathrm{n}=3$ 
Table 2 Pearson correlation of rare earth element content, soil physical and chemical properties and $\alpha$-diversity of rice bacteria at maturity stage

\begin{tabular}{lllllll}
\hline & Shannon & Inv $_{-}$ & $\begin{array}{l}\text { Observed } \\
\text { rimpson }\end{array}$ & $\begin{array}{l}\text { Pielou_ } \\
\text { richness }\end{array}$ & $\begin{array}{l}\text { Simpson_ } \\
\text { evenness }\end{array}$ & chao.value \\
\hline Soil REE content & -0.914 & -0.962 & -0.957 & -0.892 & -0.914 & -0.981 \\
Root REE content & -0.754 & -0.839 & -0.83 & -0.72 & -0.755 & -0.88 \\
Shoot REE content & -0.441 & -0.562 & -0.549 & -0.394 & -0.442 & -0.628 \\
Grain REE content & -0.589 & -0.696 & -0.685 & -0.546 & -0.589 & -0.752 \\
Total N & -0.695 & -0.588 & -0.6 & -0.731 & -0.695 & -0.52 \\
ammonia N & -0.905 & -0.956 & -0.951 & -0.882 & -0.905 & -0.976 \\
nitrate nitrogen & $-.999^{*}$ & -0.983 & -0.986 & $-1.000^{* *}$ & $-.999^{*}$ & -0.964 \\
Total P & -0.786 & -0.692 & -0.703 & -0.816 & -0.785 & -0.63 \\
available P & -0.797 & -0.705 & -0.715 & -0.827 & -0.796 & -0.644 \\
available K & -0.704 & -0.598 & -0.61 & -0.739 & -0.703 & -0.53 \\
organic matter & -0.777 & -0.682 & -0.693 & -0.809 & -0.777 & -0.62 \\
pH & 0.994 & $1.000^{*}$ & $1.000^{* *}$ & 0.987 & 0.994 & 0.994 \\
Root weight & $-1.000^{* *}$ & -0.991 & -0.993 & $-.998^{*}$ & $-1.000^{* *}$ & -0.976 \\
Leaf weight & -0.993 & $-1.000^{*}$ & $-1.000^{* *}$ & -0.986 & -0.993 & -0.994 \\
Grain weight & $-1.000^{* *}$ & -0.989 & -0.991 & $-.999^{*}$ & $-1.000^{* *}$ & -0.973 \\
\hline
\end{tabular}

**. At 0.01 level (two tailed), the correlation was significant, *. At 0.05 level (two tailed), the correlation was significant, $\mathrm{n}=3$

Table 3 Pearson correlation of rare earth element content, soil physical and chemical properties and dry weight of root, shoot and grain of rice

\begin{tabular}{|c|c|c|c|c|c|c|c|c|c|c|c|c|}
\hline & $\begin{array}{l}\text { nitrate } \\
\text { nitrogen }\end{array}$ & $\begin{array}{l}\text { Total } \\
\text { P }\end{array}$ & $\begin{array}{l}\text { availa } \\
\text { ble P }\end{array}$ & $\begin{array}{l}\text { avail } \\
\text { able } \\
\mathrm{K}\end{array}$ & $\begin{array}{l}\text { organic } \\
\text { matter }\end{array}$ & $\mathrm{pH}$ & $\begin{array}{l}\text { Total } \\
\mathrm{N}\end{array}$ & $\begin{array}{l}\text { amm } \\
\text { onia } \\
\mathrm{N}\end{array}$ & $\begin{array}{l}\text { Soil } \\
\text { REE } \\
\text { content }\end{array}$ & $\begin{array}{l}\text { Root } \\
\text { REE } \\
\text { content }\end{array}$ & $\begin{array}{l}\text { Shoot } \\
\text { REE } \\
\text { content }\end{array}$ & $\begin{array}{l}\text { Grain } \\
\text { REE } \\
\text { content }\end{array}$ \\
\hline $\begin{array}{l}\text { Root } \\
\text { weight }\end{array}$ & $.999^{*}$ & 0.783 & 0.794 & 0.701 & 0.775 & $\begin{array}{l}-0.99 \\
4\end{array}$ & 0.693 & 0.907 & 0.915 & 0.757 & 0.444 & 0.592 \\
\hline $\begin{array}{l}\text { Leaf } \\
\text { weight }\end{array}$ & 0.987 & 0.708 & 0.721 & 0.616 & 0.699 & $\begin{array}{l}-1.00 \\
0^{* *}\end{array}$ & 0.607 & 0.948 & 0.955 & 0.826 & 0.542 & 0.679 \\
\hline $\begin{array}{l}\text { Grain } \\
\text { weight }\end{array}$ & $.999^{*}$ & 0.791 & 0.802 & 0.71 & 0.783 & $\begin{array}{l}-0.99 \\
3\end{array}$ & 0.702 & 0.901 & 0.91 & 0.748 & 0.433 & 0.581 \\
\hline
\end{tabular}

**. At 0.01 level (two tailed), the correlation was significant, *. At 0.05 level (two tailed), the correlation was significant, $\mathrm{n}=3$

\section{Discussion}

Previous studies have shown that lower concentrations of rare earth can promote the growth of crops, while higher concentrations can inhibit or even harm the growth of crops ${ }^{12-13,32}$. In this study, the shoots of rice tillers cultivated in soil of $\mathrm{H}$ and $\mathrm{M}$ in rare earth mining area were significantly more than those in non mining area, especially rice of $\mathrm{M}$ with medium rare earth content grew the most densely. The dry weight of rice root, shoot and grain of soil $\mathrm{H}$ and $\mathrm{M}$ was 
significantly heavier than that of soil L. M was the heaviest, followed by $\mathrm{H}$, and L was the lightest. The results are basically consistent with previous studies. Due to extraction of ionic rare earth by $\left(\mathrm{NH}_{4}\right)_{2} \mathrm{SO}_{4}$ leaching, ammonia $\mathrm{N}$ in mining area seriously exceeded the standard, $\mathrm{pH}$ value decreased, which caused dry weight of root, shoot, grain of cultivated rice in mining area to have significant negative correlation with nitrate nitrogen, and negative correlation with total nitrogen, ammonia nitrogen, and significant positive correlation with $\mathrm{pH}$. A large number of studies have shown that there is a significant positive correlation between the REE content in crops and that in soil $^{2-5}$. In this study, the content of rare earth elements in soil is $\mathrm{H}>\mathrm{M}>\mathrm{L}$, and the content of rare earth elements in rice root, shoot and grain is $\mathrm{H}>\mathrm{M}>\mathrm{L}$, which is basically consistent with the previous research results.

Chao et $a l^{21}$ considered that the REE content is the main factor affecting the microbial structure in rare earth mining area. Jiang Zhaowei et al ${ }^{33}$; Zhou et al. ${ }^{34}$ thought that high concentration of rare earth elements had inhibitory effect on bacteria. Yang Jun et al. ${ }^{35}$ showed that when the concentration of rare earth ions reached a certain value, it had antibacterial effect, and its antibacterial effect was selective. Some studies have shown that exogenous rare earth element Yttrium destroyed the structure of soil microbial community and significantly reduced OTUs, Ace, Chao 1 and Shannon index ${ }^{36}$. Chen Xi et al. ${ }^{37}$ found that rare earth mining seriously damaged the soil quality of the mining area, caused low diversity and evenness of microbial community. In this study, the OTU number of rice bacteria in rhizosphere, root and phyllosphere cultured in soil $\mathrm{H}$ and $\mathrm{M}$ of rare earth mining area was lower than that in soil $\mathrm{L}$ of non rare earth mining area at tillering stage and maturity stage. In addition, the number of OTUs of bacteria in leaf of rice cultured in soil $\mathrm{M}$ was significantly lower than that in soil $\mathrm{L}$. The richness and Chao indexes of bacteria in rhizosphere, root and phyllosphere of rice cultured in soil $\mathrm{H}$ and $\mathrm{M}$ were significantly lower than those in soil $\mathrm{L}$ at tillering stage and maturity stage. The Shannon index of $\mathrm{H}$ and $\mathrm{M}$ was significantly lower than that of L. The Pielou's evenness index and Simpson's evenness index of $\mathrm{H}$ and $\mathrm{M}$ were lower than that of $\mathrm{L}$. It shows that the exploitation of rare earth reduces $\alpha$-diversity of rice bacteria, which is consistent with the previous research conclusions of many scholars. Mineral exploitation affects the REE content in soil, soil physical and chemical properties and rice growth, caused $\beta$-diversity of bacteria to be quite different.

Many studies have shown that soil heavy metals, physical and chemical properties, nutrient elements are important factors affecting microbial community structure ${ }^{39-40}$. Wei Zhiwen ${ }^{41}$ found that rare earth pollution affected the abundance of bacteria and fungi and changed their community structure. Wang Yousheng ${ }^{42}$ found that the contents of bacteria, fungi and Actinomycetes decreased significantly, and the abundance and diversity of soil bacteria changed significantly. However, the dominant species of soil bacteria was Firmicutes (phylum), which was related to Proteus, Actinomycetes, Bacteroidetes and Acidobacteria. Firmicutes (phylum) are affected by rare earth elements ${ }^{42,3,5}$. In this study, the abundance of Firmicum (phylum) in rice rhizosphere of $\mathrm{H}$ and $\mathrm{M}$ at tillering stage was significantly higher than that of $\mathrm{L}$, and the abundance of Firmicum (phylum) in rice rhizosphere of $\mathrm{H}$ was significantly higher than that of $\mathrm{M}$ and L; The abundance of L was significantly higher than that of $\mathrm{H}$ and $\mathrm{M}$; The abundance of Firmicutes in rice rhizosphere of $\mathrm{L}$ was significantly lower than that of $\mathrm{H}$ and $\mathrm{M}$. It can be seen that Firmicutes (phylum) in soil-plant system are sensitive to rare earth elements, but the mechanism is very complex. Actinobacteria and Acidobacteria are greatly affected by soil physical and chemical properties. The former is directly proportional to $\mathrm{pH}$ value, while the latter is 
inversely proportional to $\mathrm{pH}$ value ${ }^{3,5}$. The $\mathrm{pH}$ value of rare earth mining area was reduced by mineral exploitation, and the abundance of Actinobacteria in rice rhizosphere of $\mathrm{L}$ was significantly higher than that in $\mathrm{H}$ and $\mathrm{M}$, and the abundance of acidobacteria in rice rhizosphere of $\mathrm{L}$ was significantly lower than that in $\mathrm{H}$ and $\mathrm{M}$.

The exploitation of rare earth minerals significantly reduced the diversity and evenness of soil-plant system microorganisms, and enhanced the resistance and growth of some bacteria, resulting in the formation of some dominant bacterial genera in rare earth mining area. For example, due to mineral exploitation, a large amount of acid mineral water was formed, and the abundance of Candida solibacter and Candida koribacter in rice rhizosphere of $\mathrm{M}$ soil was higher ${ }^{43}$. Many dominant bacteria can promote the growth of rice, increase the yield of rice, and make the dry weight of rice root, shoots and grain be highly or extremely significantly negatively correlated to $\alpha$-diversity of bacteria. Some scholars believe that the biological effect of rare earth ions may be similar to that of $\mathrm{Ca}$ ions because the radius of rare earth ions is close to that of $\mathrm{Ca}$ ions, Rare earth ions may occupy or replace $\mathrm{Ca}$ ions in organisms ${ }^{44-45}$. Some researchers have explored the mechanism of the interaction between rare earth ions and microorganisms at the protein level. They believe that rare earth ions can affect the production of differential proteins by microorganisms, thus controlling the growth, reproduction and metabolism of microorganisms ${ }^{46-47}$. The differential proteins mainly include transporters, stress-related proteins, metabolism related proteins, etc. Chai Ruijuan et al. ${ }^{48}$ found that the effect of rare earth ions on promoting microbial reproduction was inhibited by chlorpromazine, indicating that the mechanism of $\mathrm{La}$ and $\mathrm{Ce}$ promoting bacterial growth may be related to calmodulin.

Soil environment, plants and microorganisms interact with each other, soil and plants affect bacteria, and bacteria also react on plants and soil ${ }^{49}$. Bacteria in soil-plant system can be divided into beneficial bacteria, neutral bacteria and harmful bacteria. Harmful bacteria harm plant growth, and beneficial bacteria can play an important role in promoting plant growth, nutrient absorption and stress response ${ }^{50-53}$. Due to mineral exploitation, the REE content and ammonia nitrogen in soil increased significantly, the vegetation was destroyed, and the content of organic matter was low, which affected the ecological environment ${ }^{54}$. At tillering stage, Ralstonia abundance in root, rhizosphere, leaf of rice in $\mathrm{H}$ soil was high, accounting for $17.8 \%, 2.18 \%$ and $8.12 \%$ respectively. Ralstonia is a plant pathogenic bacteria, affecting the growth of rice ${ }^{55}$, which may be one of the reasons why the dry weight of root, shoot and grain of group $\mathrm{H}$ is lower than that of group $\mathrm{M}$. The abundance of Herbaspirillum, Azospirillum and Bacillus in rice root, the abundance of Azospirillum in rice root and rhizosphere, The abundance of Bacillus in rice root, rhizosphere, leaf and phyllosphere of $\mathrm{H}$ is relatively high. Nitrogen fixation of Herbaspirillum and Azospirillum can promote plant growth, nutrient absorption and photosynthetic efficiency ${ }^{56-58}$. Bacillus has strong growth promoting effect on rice, potential antibacterial activity and strong antagonistic activity. It can produce iron carrier in iron limited medium and produce four kinds of secondary metabolites, causing damage to cell membrane of Magnaporthe grisea ${ }^{59-60}$. These beneficial bacteria may be an important reason why rice biomass in $\mathrm{H}$ group is significantly higher than that in $\mathrm{L}$ group.

Because of mineral exploitation, soil rare earth elements, total nitrogen, ammonia nitrogen and nitrate nitrogen in $\mathrm{M}$ were significantly higher than those in non mining areas, $\mathrm{pH}$ decreased, soil acidity increased, forming a compound pollution of rare earth and ammonia nitrogen, causing bacterial species to be monotonous. At tillering stage, Burkholderia abundance in rice root and rhizosphere of $\mathrm{M}$ was very high, and Acinetobacter, Buttiauxella and Comamonas abundance in 
rice leaf was very high. Burkholderia is a microorganism with the ability to degrade ammonia nitrogen efficiently. It can transform ammonia nitrogen into substances needed by itself or beneficial to the environment. It has the functions of biological control, promoting plant growth, decomposing toxic substances and bioremediation. It is a potential genus for remediation of high ammonia nitrogen pollution in rare earth mine wasteland in South Jiangxi Province ${ }^{61}$. Acinetobacter can improve the resistance of plants to $\mathrm{Cu}$, the ability to remove $\mathrm{Ni}$ and the ability to separate rare earth elements ${ }^{62-64}$. Buttiauxella could significantly increase the biomass and chlorophyll content of shoots and roots of plants treated with $\mathrm{Cd}^{65}$ and Comamonas also had a good ability to degrade a variety of environmental pollutants ${ }^{66}$. These beneficial bacteria may be an important reason for the higher biomass of rice in $\mathrm{M}$ than that in $\mathrm{H}$ and $\mathrm{L}$.

In the maturity stage, Burkholderia, Bradyrhizobium, Ideonella and Pleomorphomonas were found in rice rhizosphere of $\mathrm{H}$. the abundance of Geobacter and Denitisoma was higher. The abundance of Bradyrhizobium in rice roots of $\mathrm{M}$ was especially high in maturity stage, and the abundance of Geobacter and Candida_koribacter in rice rhizosphere was high. Bradyrhizobium Rhizobium not only colonizes in legumes, but also in rice. The symbiosis between Bradyrhizobium Rhizobium and rice can achieve biological nitrogen fixation, which plays an important role in ensuring food security and ecological construction ${ }^{67}$. These fungi may be another important reason why rice yield of $\mathrm{H}$ and $\mathrm{M}$ is significantly higher than that of $\mathrm{L}$.

The contents of available P and ammonia nitrogen in L soil were significantly lower, and the relative abundances of Pantoea and Acidovorax in rice roots were higher at tillering stage. Acidovorax is the pathogen of brown streaked disease of rice ${ }^{68}$, which may be one of the reasons why rice yield of $\mathrm{L}$ is lower than that of $\mathrm{H}$ and M. Pantoea can promote the growth of alfalfa, promote the growth of wheat root and shoot, improve the availability of phosphorus in soil, and reduce the application of fertilizer ${ }^{69}$. The relative abundance of Exiguobacterium in rice phyllosphere of L is high. Some studies have shown that it has broad-spectrum antibacterial effect on Gram-positive and gram-negative foodborne pathogenic bacteria. It has antagonistic effect on a variety of plant pathogenic fungi. It shows the ability of nitrogen fixation, phosphate solubilization and iron carrier generation ${ }^{70-71}$. The relative abundance of Weissella in leaves is high, which is beneficial bacteria ${ }^{72}$. The relative abundances of Bradyrhizobium, Ideonella, Methylocystis, Streptomyces and Georgfuchsia were higher in rice roots at maturity stage. Methylocystis can inhibit the growth of Staphylococcus albicans and Bacillus subtilis with spores, produce single cell protein, and have an important impact on the global C cycle ${ }^{73}$. Streptomyces has the potential of biocontrol against plant pathogenic fungi ${ }^{74}$. Georgfuchsia is an aromatic compound degrading bacterium in aquifers ${ }^{75}$. These beneficial bacteria may be an important reason for the healthy growth of L rice under the condition of low soil fertility.

At tillering stage, Ralstonia was relatively abundant in rice root of $\mathrm{H}$ soil and moved vertically to leaf, resulting in higher relative abundance of Ralstonia in leaf; The relative abundance of Ideonella and Bacillus in rice rhizosphere was high, and moved horizontally to the root and leaf of rice, resulting in higher relative abundance in root and leaf; The relative abundance of Burkholderia and Buttiauxella in the rice rhizosphere of $\mathrm{M}$ was high, and moved horizontally to the root and leaf of rice, resulting in higher relative abundance of Burkholderia and Buttiauxella in the root and leaf; The relative abundance of Exiguobacterium in rice phyllosphere of L was high, and it moved horizontally into leaf, so that the relative abundance of Exiguobacterium in the leaf was also high. The relative abundance of Azospira, Anaeromyces 
Obacter and Georgfuchsia in the rice rhizosphere of $\mathrm{H}$ was higher in the maturity stage, and moved horizontally to the root, which made the relative abundance of Azospira higher in the root. The horizontal movement of these bacteria makes them play an active role in the process of rice growth and become an important reason for the healthy growth of rice ${ }^{76}$.

\section{Conclusion}

1) The REE contents in rice roots, shoots and grains were significantly positively correlated with those in soil, causing the REE contents in all parts of rice in mining area to be significantly higher than those in non mining area. The dry weight of rice roots, shoots and grains was highly correlated with soil physical and chemical properties, nutrient elements and rare earth elements.

2) The exploitation of rare earth minerals inhibited $\alpha$-diversity of bacteria in rhizosphere, root, phyllosphere and leaf of rice, significantly reduced the abundance index of OTU number, Chao1 and Ace index, decreased the diversity index of Shannon and inv-Simpson index, reduced the evenness index: Pielou's event index, Simpson's evenness index, etc., which caused $\beta$-diversity of bacterial to be different; Rare earth elements enhance the resistance and growth of some bacteria, and form some dominant bacteria genera in the rare earth mining area. They play an important role in promoting plant growth, nutrient absorption and stress response, which has become an important reason for the dry weight of rice cultivated in the soil of $\mathrm{H}$ and $\mathrm{M}$ in the mining area is significantly higher than that of $\mathrm{L}$ in non mining area.

3) Rare earth minerals reduce the diversity of bacteria, but form the dominant bacteria, such as Burkholderia, Bacillus, Buttiauxella, Acinetobacter, Bradyrhizobium, Candida koribacter, which can degrade the pollutants formed by rare earth mining, alleviate the compound pollution of rare earth and ammonia nitrogen, and have the functions of nitrogen fixation and resistance to rare earth stress; The content of soil available phosphorus in non mining area is low, forming the dominant bacteria of Pantoea, which has the function of improving soil phosphorus availability.

4) Soil rare earth elements and soil physical and chemical properties affect the community structure of bacteria in rhizosphere and phyllosphere of rice, promote the parallel movement of some bacteria in rhizosphere, root, phyllosphere and leaf of rice, promote the construction of community structure of bacteria in rhizosphere and phyllosphere of rice, give full play to the growth promoting function of Endophytes, and promote the growth of rice.

\section{Materials and methods}

\section{Soil collection and material preparation}

The sampling point of rare earth mining area are 1500 meters away from REE mining area (latitude and longitude is $115^{\circ} 42^{\prime} 6^{\prime \prime} \mathrm{E}, 24^{\circ} 52^{\prime} 9^{\prime \prime} \mathrm{N}$ ) in Shipai village, Wenfeng Township, Xunwu County, southern Jiangxi Province; 1500 meters away from REE mining area (latitude and longitude is $114^{\circ} 59^{\prime} 36^{\prime \prime} \mathrm{E}, 25^{\circ} 23^{\prime} 57^{\prime \prime} \mathrm{N}$ ) in Longshe village, Jiading town, Xinfeng Countyy, southern Jiangxi Province and the sampling point of non REE mining area is located in Choukou village, Maojialing Township, Xinzhou District, Shangrao City of Jiangxi Province(longitude and latitude is $\left.117^{\circ} 57^{\prime} 46^{\prime \prime} \mathrm{E}, 28^{\circ} 25^{\prime} 1^{\prime \prime} \mathrm{N}\right) .50 \mathrm{~kg}$ of $20 \mathrm{~cm}$ topsoil were collected at three sampling points respectively. Air dry the soil sample naturally, remove the grass roots, litter, stones and other debris, and sift through 100 mesh for standby. The tested soil was loaded into a $26 \mathrm{~cm}$ high 
and $22 \mathrm{~cm}$ diameter rigid PVC bucket with $5 \mathrm{~kg}$ of soil, $5.4 \mathrm{~g}$ of urea (containing $46.6 \% \mathrm{n}$ ), $0.6 \mathrm{~g}$ of potassium chloride (containing $62.9 \% \mathrm{~K}_{2} \mathrm{O}$ ) and $1.00 \mathrm{~g}$ of superphosphate (containing $14.0 \%$ $\mathrm{P}_{2} \mathrm{O}_{5}$ ). The soil was mixed with $\mathrm{N}, \mathrm{P}$ and $\mathrm{K}$ fertilizers, and rice was planted after a week of submergence.

\section{Rice pot experiment and sample collection}

Rice variety Jiangzao 361 was purchased from Jiangxi Keyuan Seed Industry Co., Ltd. The whole growth period of this variety is 110.2 days. After participating in the regional test of rice in Jiangxi Province from 2013 to 2014, it is widely planted in Jiangxi Province. The seeds were disinfected with $10 \% \mathrm{H}_{2} \mathrm{O}_{2}$ solution for 15 min, then washed with water for many times.

After germination, the seeds were sown in the soil without rare earth pollution for seedling raising. Four weeks later, the rice seedlings were transplanted into PVC buckets with culture soil prepared. Two seedlings were transplanted into each barrel. The pot experiment was carried out in the greenhouse. The daily illumination, duration of illumination, temperature and humidity of the greenhouse were adjusted to be close to the outdoor. According to the growth characteristics of Jiangzao 361 rice variety, the pot-experiment rice was managed in combination with the experience and methods of rice planting management in Jiangxi Province. According to the REE content in soil, the samples were labeled as H, M and L. The soil with highest REE content was H, the lowest was L, and the one between them was M. Because three replicates were made for each sample, the pot-experiment rice was labeled with H1, H2, H3, M1, M2, M3, L1, L2, L3 respectively.

Rhizosphere soil, rice roots, shoots were collected at tillering stage, and rhizosphere soil and rice roots were collected at maturity stage, which was used for molecular experiments.

After maturity of rice, the roots, shoots and millet of rice were harvested respectively, washed with deionized water, then placed in the ventilated room and dried naturally until constant weight and weighed. Husk the millet and collect the unpolished rice. The unpolished rice, shoot and root were ground into powder and stored at room temperature for analysis.

\section{Chemical analysis}

The soil physical and chemical properties and nutrient elements are tested by the relevant detection methods in the Agricultural Industry Standard of the People's Republic of China (2006). Soil pH determination: NY/T 1121.2-2006, determination of total $\mathrm{P}$ in soil: alkali soluble molybdenum antimony anti spectrophotometry HJ632-2011, determination of soil available phosphorus: sodium bicarbonate extraction molybdenum antimony anti spectrophotometry HJ704-2014, determination of soil ammonia nitrogen, nitrite nitrogen and nitrate nitrogen: potassium chloride solution extraction spectrophotometry HJ634-2012, determination of soil available K and slow acting potassium content: NY/t889-2004, Determination of soil organic matter: NY/T 1121.6-2006. The test results can been seen in Table 4.

Add $0.25 \mathrm{~g}$ of soil sample in a $100 \mathrm{ml}$ digestion tube (three replicates for each sample), add 5 $\mathrm{ml}$ aqua regia $\left(\mathrm{HNO}_{3}: \mathrm{HCl}=3: 1\right)$, balance overnight at room temperature, and then heat to $120^{\circ} \mathrm{C}$ for $12 \mathrm{~h}$, then warm to $140{ }^{\circ} \mathrm{C}$ until the soil color turns white, and the digestion procedure refers to reference 3. After digestion, the sample was cooled in a fume hood and diluted to $50 \mathrm{ml}$ with ultrapure water. After filtratiion with $0.45 \mathrm{um}$ membrane, the contents of 15 rare earth elements (Y, La, Ce, Pr, Nd, Sm, Eu, Gd, Tb, Dy, Ho, Er, Tm, Yb, Lu) were determined by ICPMS-2030 (Shimadzu Corporation, Shimadzu Institute, Kyoto, Japan). The quality was monitored by the standard reference substance GBW07405 of the national standard substance research center. The 
test results are shown in Table 1.

Add $0.2 \mathrm{~g}$ of crushed unpolished rice, $0.1 \mathrm{~g}$ of shoot, and $0.1 \mathrm{~g}$ of root to a $50-\mathrm{ml}$ polyethylene centrifuge tube (three replicates for each sample) respectively, soaked in $3 \mathrm{ml}$ of superior pure nitric acid overnight, and digested in a microwave digestion oven (Mars, Matthew Inc., USA), The whole process of digestion was controlled by GBW07603 (GSV-2), a national first-class reference material (Institute of Geophysical and Geochemical Exploration, Ministry of Geology and Mineral Resources of China). The digestion solution was diluted to $50 \mathrm{ml}$ with ultrapure water, filtered with $0.45 \mu \mathrm{m}$ membrane. The contents of 15 rare earth elements were determined by ICPMS-2030.

Table 4 Soil physical and chemical properties, nutrient elements and REE content (mg/kg)

\begin{tabular}{|c|c|c|c|c|c|c|c|c|c|}
\hline $\begin{array}{l}\text { Sample } \\
\text { Name }\end{array}$ & pH & Total N & $\begin{array}{l}\text { Ammonia } \\
\mathbf{N}\end{array}$ & $\begin{array}{l}\text { Nitrate } \\
\mathbf{N}\end{array}$ & Total P & $\begin{array}{l}\text { Available } \\
\text { P }\end{array}$ & $\begin{array}{l}\text { Available } \\
\text { K }\end{array}$ & $\begin{array}{c}\text { organic } \\
\text { matter } \\
(\%)\end{array}$ & $\begin{array}{c}\text { REE } \\
\text { content }\end{array}$ \\
\hline H1 & 5.28 & 1351.96 & 308.37 & 29.7 & 338.9 & 13.59 & 70.82 & 2.81 & 916.56 \\
\hline L1 & 6.58 & 1425.36 & 198.08 & 24.98 & 114.49 & 4.03 & 77.32 & 4.58 & 140.13 \\
\hline M1 & 4.97 & 2624.05 & 311.43 & 34.27 & 1141.24 & 87.1 & 81.5 & 5.67 & 824.05 \\
\hline $\mathrm{H} 2$ & 5.52 & 1425.31 & 124.37 & 29.33 & 180.6 & 9.9 & 83.34 & 4.11 & 805.64 \\
\hline L2 & 6.63 & 1551.15 & 38.55 & 25.33 & 112.93 & 1.44 & 85.49 & 4.05 & 110.33 \\
\hline M2 & 5.2 & 2839.02 & 113.75 & 31.65 & 1220.12 & 106.47 & 111.49 & 5.34 & 735.09 \\
\hline
\end{tabular}

Note: H1, M1 and L1 are rice and soil samples in tillering stage, H2, M2 and L2 are rice and soil samples in maturity stage, the same below.

\section{Pretreatment and DNA extraction of soil and plant samples}

The loose and massive soil of rice root samples were removed, and then immersed in $15 \mathrm{ml}$ PBS buffer containing Silwet L-77 (pH 7.0, 0.02\% Silwet L-77) and shook in shaking table for 10 min. Then the suspension obtained was poured into a sterile centrifuge tube and centrifuged at $6000 \mathrm{~g}$ for $5 \mathrm{~min}$. The precipitates were taken as rhizosphere soil samples and stored at $-80^{\circ} \mathrm{C}$ for subsequent DNA extraction. After shaking, the roots were washed in $75 \%$ ethanol for $10 \mathrm{~min}$, $2.5 \%$ sodium hypochlorite for $10 \mathrm{~min}$, and finally washed in sterile water for 5 times to remove the residual microorganisms on the root surface (scanning electron microscope was used to check whether it was clean). The cleaned roots were defined as root samples ${ }^{77,78}$. The root samples were ground in PBS with sterile mortar and pestle, washed into the centrifuge tube and left for 30 minutes. The supernatant was centrifuged at $6000 \mathrm{~g}$ for $5 \mathrm{~min}$, and the cell particles obtained (endophyte samples) were stored at $-80^{\circ} \mathrm{C}$ for subsequent DNA extraction.

The leaves were placed in a sterile conical flask ( $250 \mathrm{ml}$ volume) with $100 \mathrm{ml}$ PBS (pH 7.0, $0.02 \%$ Silwet L-77) and stirred violently for $30 \mathrm{~min}$. the leaves were then ultrasonically washed in water bath for $10 \mathrm{~min}$. The supernatant (phyllobacteria sample) was concentrated at $0.22 \mu \mathrm{M}$ nitrocellulose membrane filter. Before extraction of DNA, the membrane was stored at $-80^{\circ} \mathrm{C}$. Then the leaves were washed in $75 \%$ ethanol for $3 \mathrm{~min}, 2.5 \%$ sodium hypochlorite for $5 \mathrm{~min}$, and washed with sterile water for 5 times. Then the leaves were ground in PBS with sterile mortar and pestle, washed into the centrifuge tube and left for 30 minutes. The supernatant was transferred to a new centrifuge tube and centrifuged at $6000 \mathrm{~g}$ for $5 \mathrm{~min}$. The extracted cell microspheres (endophyte samples) were stored at $-80^{\circ} \mathrm{C}$ before DNA extraction.

The soil samples of rice rhizosphere were pretreated with propidium monoazide (PMA) to remove the DNA interference of dead microorganisms ${ }^{79}$. Then, the DNA of bacteria sample in 
rhizosphere soil, root, phyllosphere and leaf was extracted by FastDNA ${ }^{\mathrm{TM}}$ SPIN Kit for Soil(MP Biomedicals LLC, USA). The DNA concentration and purity were determined by nanodrop 2000 , and then stored at $-20^{\circ} \mathrm{C}$ in refrigerator for subsequent $16 \mathrm{~S}$ rRNA gene analysis.

\section{Amplification and sequencing of 16S r RNA gene}

The V4 region of $16 \mathrm{~S}$ rRNA was amplified by bacterial specific primers $515 \mathrm{~F}\left(5^{\prime}\right.$ GTGCCAGCMGCCGCGGTAA-3') and 806R (5'-GGACTACHVGGGTWTCTAAT-3'). Phusion high fidelity enzyme (high fidelity PCR master with GC buffer) was used in PCR. The process was as follows: pre-denaturation for $5 \mathrm{~min}$ in $95^{\circ} \mathrm{C}$, denaturation for $30 \mathrm{~s}$ in $94^{\circ} \mathrm{C}$, annealing for $35 \mathrm{~s}$ in $55^{\circ} \mathrm{C}$, extension for $30 \mathrm{~s}$ in $72{ }^{\circ} \mathrm{C}$. there were 30 cycles above, then extension for $8 \mathrm{~min}$ in $72{ }^{\circ} \mathrm{C}$. The gel Life Technology (USA) was used for recovery and purification. After being qualified by gel electrophoresis, the accurate double stranded DNA concentration was quantified by Qubit3.0 (Life Technology, USA).

The NEB kit was used to construct the library, The standard database building process of DNA Library Prep Kit for Illumina. NEBNext Ultra (NEB\#e7370S/L) was adopted. The length distribution and concentration of the constructed library was detected by aglent 2100 and qPCR, respectively. The qualified library was sequenced by Illumina hiseq2500 (PE250 reads). The sequencing samples included soil and plant samples (rhizosphere soil samples, phyllospheric bacteria samples, endophytic bacteria samples in leaves and endophytic bacteria samples in roots) at tillering stage and maturity stage. The data obtained after sequencing were used for quality control.

The 16S rRNA gene sequences obtained by high-throughput sequencing were pre-treated and quality controlled by QIIME2 software. Quality control adopted the parameters recommended by Bokulich et al. ${ }^{31}$ According to the sequence similarity, they were classified into multiple OTUs. Those gene sequences with similarity level of 0.03 ( $97 \%$ sequence similarity, approximately equal to species level) were selected for subsequent analysis, and the OTU representative sequence was annotated. The reference sequence from Silva database (db128 version) is used, the command of mothur software (classify. SEQS) is used for annotation, and RDP algorithm is used for annotation algorithm.

\section{Statistical analysis}

QIIME2 software was used to analyze the a-diversity (richness index, Simpson evenness index, Shannon index, etc.) and $\beta$-Diversity (based on UniFrac and Bray Curtis equidistance matrix) of different samples was analyzed by $R$ software vegan package. Nonparametric multivariate statistical algorithms such as PERMANOVA.ANOSIM in vegan package of $R$ software were used to analyze the effects of soil basic physical and chemical properties, nutrient factors and REE content on rice. Pearson test, canonical correspondence analysis (CCA) and variation partitioning analysis (VPA) based on CCA were used to analyze the contribution of environmental variables to bacterial community. Origin9.0 is used to draw Heatmap, Software of Metasee and Qiime are used for data visualization ${ }^{6,21}$.

\section{Statement on guidelines as experimental research and field studies on rice}

Experimental research and field studies on rice (cultivated rice and wild rice), including the collection of rice comply with relevant institutional, national, and international guidelines and legislation in the methods section. The measurement process of microorganism and rare earth content in different parts of rice will not affect the local soil microorganism and ecological environment, etc. During the process of experiment, aseptic sampling was carried out to avoid 
contamination. The experimental group and control group have been tested at the same time, and the whole experimental process of the research is safe, which is based on references as below.

1.The methods of soil collection and material preparation are mainly from reference 2-5.

2.The methods of potted rice and sample collection are mainly from reference 3-5.

3.The soil physical and chemical properties and nutrient elements were detected by the relevant detection methods in the Agricultural Industry Standard of the People's Republic of China (2006).

4.The determination methods of rare earth elements in soil and rice are mainly from reference 2-5.

5.The pretreatment and DNA extraction of soil and plant samples are mainly from reference 77-79.

6.Amplification and sequencing of $16 \mathrm{~S} r$ RNA gene is mainly from references 31 and 35 .

7. Statistical analysis is mainly from references 6 and 21 .

\section{Acknowledgments}

This work was supported by the National Natural Science Foundation of China (Grant No. 41867062\&41561096) and Science and Technology Projects of Educational Department in JiangXi Province of China (Grant No. 190885)

\section{References}

1. Kynicky, J., Smith, M. P., Xu, C. Diversity of rare earth deposits:the key example of China. Elements 8 (5), 361-367. https://doi.org/10.2113/gselements.8.5.361 (2012)

2.Jin, S. L., Huang, Y. Z., Hu, Y., et al. Rare earth elements content and health risk assessment of soil and crops in typical rare earth mine area in Jiangxi Province. Acta Sci Circum 34, 3084-3093. https://doi.org/10.13671/j.hjkxxb.2014.0799 (2014) (in Chinese)

3..Jin, S,L., Hu, Z.J., Man, B.Y., Pan, H.H., Kong, X., Jin, D.C. Application of phosphate-containing materials affects bioavailability of rare earth elements and bacterial community in soils. Sci China Technol Sc 62,1616-1627. https://doi.org/10.1007/s11431-018-9426-3 (2019)

4. Jin, S.L., Hu, Z.J., Huang, Y.Z., Hu, Y, Pan, H.H. Evaluation of several phosphate amendments on rare earth element concentrations in rice plant and soil solution by X-ray diffraction. Chemosphere 236,124322 https://doi.org/10.1016/j.chemosphere. 2019.07 .053 (2019)

5..Jin, S. L., Jin, W., Bai, Y. J., Dong, C. X., Jin, D. C., Hu, Z.J., Huang, Y. Z. Response of rice and bacterial community to phosphorus-containing materials in soil-plant ecosystem of rare earth mining area.J Hazard Mater 381,121004 https://doi.org/10.1016/j.jhazmat.2019.121004 (2020)

6.Chen, Y., Chao, Y., Li, Y., Lin, Q., Bai, J., et al. Survival strategies of the plant-associated bacterium Enterobacter sp. strain EG16 under cadmium stress. Appl Environ Microb 82, 1734-1744. https://doi.org/ 10.1128/ AEM.03689-15 (2016)

7.Shajib, M.T. I. , Hansen, H.C.B., Liang, T., Holm, P. E. Rare earth elements in surface specific urban runoff in Northern Beijing. Sci Total Environ 717, 136969 https://doi.org/10.1016/j.scitotenv.2020.136969 (2020)

8.Liang, T., Li, K. X.., Wang, L. Q. 2014. State of rare earth elements indifferent environmental components in mining areas of China. Environ Monit Assess 186, 1499-1513. https://doi.org/10.1007/s10661-013-3469-8 (2014)

9.Gao, Z. Q., Zhou, Q. X. 2011. Contamination from rare earth ore strip mining and its impacts on resources and eco-environment. Chinese J Ecol 30, 2915-2922. https://doi.org/10.13292/j.1000-4890.2011.0421 (2011) (in 
Chinese)

10. Chen, Z. Y. Environmental behavior, biological toxicity of rare earth and its potential hazard in agriculture application. Chinese National Symposium on Analytical Chemistry of rare earth elements. (2007) (in Chinese).

11.Li, S. Y., Fu, H. J., Dong, W. Research progress on the interaction of microorganisms and rare earth. J Jiangxi Univer Sci Technol, 38,56-62 https://doi.org/10.13265/j.cnki.jxlgdxxb.2017.03.009 (2017) (in Chinese)

12.Jin, S. L., Huang, Y. Z. A review on rare earth elements in farmland ecosystem. Acta Ecol Sin 33, 4836-4845. https://doi.org/10.5846/stxb201212311902 (2013) (in Chinese)

13.Jin, S. L., Huang, Y. Z. A review on ecological toxicity of rare earth elements in soil. Asian J Ecotox, 9, 213-223 https://doi.org/10.7524/AJE.1673-5897.20130312001 (2014) (in Chinese)

14.Yang, R. L., Chen, W. D., Wu, X. Y., Liu, X. M. Progress on effect of rare earth on growth, mechanism, and application of microorganism J Chin Rare Earth Soc, 23, 110-115 (2005) (in Chinese)

15.Chu H. Y., Zhu, J. G., Xie,Z. B., et al. Effects of rare earth element lanthanum on the activities of invertase, catalase and dehydrogenase in red soil. Chin Environ Sci, 21,77-80. https://doi.org/10.3321/j.issn:1000-6923.2001.01.020 (2001) (in Chinese)

16.He, Q. Z., Yu, H., Zhou, M. F., Xu, Y. M., Shen, J. Y. Synthesis, characterization and biological activity of rare earth complexes with L-aspartic acid and o-phenanthroline. $J$ Chin Rare Earth Soc 25, 150-155 https://doi.org/10.3321/j.issn:1000-4343.2007.02.004 (2007) (in Chinese)

17.Wang Y. S., Hou, X. L., Cai, L. P., Ma, X. Q. Impacts of rare earth mining on soil bacterial community composition and biodiversity. Chin Environ Sci 37, 3089-3095.

https://doi.org/10.3969/j.issn.1000-6923.2017.08.034 (2017) (in Chinese)

18.Wang J. H Study on characteristics of soil microbe in exogenous rare earths accumulation area of Baogang tailings dam Dissertation for Master Degree Inner Mongolia Normal University of China https://doi.org/10.7666/d.y1891887 (2011).

19.Pol, A., Barends, T. R. M., Dietl, A., Khadem, A. F., Eygensteyn,J., Jetten, M. S. M., Op den Camp, H. J. M. Rare earth metals are essential for methanotrophic life in volcanic mudpots. Environ Microbiol 16 , 255-264. https://doi.org/10.1111/1462-2920.12249 (2014)

20.Keltjens, J. T., Pol, A., Reimann, J., Op den Camp, H. J. M. PQQ-dependent methanol dehydrogenases: rare-earth elements make a difference. Appl Microbiol Biotechnol 98, 6163-61. https://doi.org/10.1007/s00253-014-5766-8 (2014)

21.Chao, Y.Q., Liu, W.S., Chen, Y.M., Chen, W.H., Zhao, L.H., Ding, Q.B., Wang, S.Z., Tang, Y.T., Zhang, T., Qiu, R. L. Structure, Variation, and Co-occurrence of Soil Microbial Communities in Abandoned Sites of a Rare Earth Elements Mine. Environ. Sci. Technol. 50, 11481-11490 https://doi.org/10.1021/acs.est.6b02284 (2016)

22.Avishek, B., Gautam, K. D., Padmini, S., et al. Application of rice (oryza sativa 1.) root endophytic diazotrophic azotobacter sp. strain avi2 (mcc 3432) can increase rice yield under green house and field condition.Microbiol Res 219, 56-65. https://doi.org/10.1016/j.micres.2018.11.004 (2019)

23.Upson, R., Read, D. J., Newsham, K. K. Nitrogen form influences the response of deschampsia antarctica to dark septate root endophytes. Mycorrhiza, 20, 1-11. https://doi.org/10.1007/s00572-009-0260-3 (2009)

24.Napier, R. M., Venis, M. A. Auxin action and auxinbinding proteins. New Phytol, 129, 167-201. https://doi.org/10.1111/j.1469-8137.1995.tb04291.x (1995)

25. Ramesh, K. S., Namrata, M., Surenda, S. Improved nutrient use efficiency increases plant growth of rice with the use of iaa-overproducing strains of endophytic burkholderia cepacia strain RRE25. Microb Ecol, 66, 375-384. https://doi.org/10.1007/s00248-013-0231-2 (2013) 
26.Raheem, S., Muhammad, W., Abdul, L. K., et al. Seed-borne endophytic bacillus amyloliquefaciens rwl-1 produces gibberellins and regulates endogenous phytohormones of oryza sativa. Plant Physiol. Bioch 106, 236-243. https://doi.org/10.1016/j.plaphy.2016.05.006 (2016)

27.Berg, G., Hallmann, J. Control of plant pathogenic fungi with bacterial endophytes. Microl Root Endophy 9 , 53-69 https://doi.org/10.1007/3-540-33526-9_4 (2006)

28.Xu, T., Cao, L., Zeng, J., et al. The antifungal action mode of the rice endophyte streptomyces hygroscopicus OsiSh-2 as a potential biocontrol agent against the rice blast pathogen. Pestic Biochem Phys 160, 58-69 https://doi.org/10.1016/j.pestbp.2019.06.015 (2019)

29.Zhou, J. Y., Li, P., Meng, D., et al. Isolation, characterization and inoculation of Cd tolerant rice endophytes and their impacts on rice under $\mathrm{Cd}$ contaminated environment. Environ Pollut 260, 113990 https://doi.org/10.1016/j.envpol.2020.113990 (2020)

30. Valeria, F. F., Sandra, M. R., Sandra, M. R., Thaura G. H. Are endophytic bacteria an option for increasing heavy metal tolerance of plants? a meta-analysis of the effect size. Front Env Sci-Switz 8,603668 https://doi.org/10.3389/fenvs.2020.603668 (2021)

31.Bokulich, N. A., Subramanian, S., Faith, J. J., Gevers, D., Gordon, J. I., et al. Quality-filtering vastly improves diversity estimates from Illumina amplicon sequencing. Nat Methods, 10, 57-59 https://doi.org/10.1038/nmeth.2276 (2013)

32.Xia C. F. Study on the Interaction of Light Rare Earths and Mitochondria and Its Mechanism. Dissertation for Doctor Degree Wuhan University of China (2013).

33.Jiang, Z. W., Weng, B. Q., Huang, Y. F., et al. Effects of Lanthanum on Soil Microorganism. J China Rare Earth 26, 498-502. https://doi.org/10.3724/SP.J.1011.2008.00534 (2008) (in Chinese)

34. Zhou, J., Xia, B., Treves, D.S., et al. Spatial and resource factors influencing high microbial diversity in soil. Appl Environ Microbiol, 68, 326-334 https://doi.org/10.1128/AEM.68.1.326-334.2002 (2002)

35.Yang, J., Zhang, H., Wang, J. C., et al. Inhibition of Rare earth on bacteria and fungi. Chin Rare Earth 30 , 35-39 https://doi.org/10.3969/j.issn.1004-0277.2009.01.009 (2009) (in Chinese)

36..Luo, C.G., Deng, Y. W., Liang, J., Zhu, S. P., Wei, Z. Y., Guo, X. B., Luo, X. P. Exogenous rare earth element-yttrium deteriorated soil microbial community structure. $J$ Rare Earth 3, 430-439 https://doi.org/10.1016/j.jre.2017.10.003 (2018) (in Chinese)

37. Chen, X, Liu Y Z, Li J Q, Ge G, Wu L, Li Y X. Response of a rare earth tailing soil bacterial community structure to vegetation restoration. Acta Ecol Sin 36, 3943-3950. https://doi.org/10.5846/stxb201411182280 (2016) (in Chinese)

38. Deng, H., Li, X. F., Cheng, W. D., Zhu, Y. G. Resistance and resilience of Cu-polluted soil after Cuperturbation, tested by a wide range of soil microbial parameters. Fems Micro Ecol 70, 293-304. https://doi.org/10.1111/j.1574-6941.2009.00741.x (2009)

39. Chen, L. X., Li, J. T., Chen, Y. T., Huang, L. N., Hua, Z. S., et al. Shifts in microbial community composition and function in the acidification of a lead/zinc mine tailings. Environ Microbiol, 15, 243 1-2444. https://doi.org/10.2136/sssaj2008.0276 (2013)

40. Zhou, J., Ning, D. Stochastic community assembly: does it matter in microbial ecology? Microbiol Mol Biol R 81, e0002-17. https://doi.org/10.1128/MMBR.00002-17 (2017)

41. Wei, Z. W. .Study on the bacterial diversity in the restoration area of rare earth mine tailings of Gannan. Dissertation for Doctor Degree Jiangnan University of China (2019) (in Chinese)

42. Wang Y. S. Effect of rare earth mining on red soil ecosystem and revegetation mechanism in its wasteland. Dissertation for Doctor Degree Fujian agriculture and Forestry University of China (2016) (in Chinese)

43. Wang, H., Zeng, Y. F., Guo, C. L., Bao, Y. P., Lu, G. N., Reinfelder, J. R., Dang, Z. Bacterial, archaeal, and 
fungal community responses to acid mine drainage_laden pollution in a rice paddy soil ecosystem. Sci Total Environ. 616-617, 107-116 https://doi.org/10.1016/j.scitotenv.2017.10.224 (2018)

44. Pickard, B. G. Comparison of calcium and lanthanon Ions in the Avena-coleoptile growth test. Planta 91, 314 https://doi.org/10.1007/BF00387504 (1970)

45. Moriwaki, H., Koide, R., Yoshikawa, R., Warabino, Y., Yamamoto, H. Adsorption of rare earth ions onto the cell walls of wild-type and lipoteichoic acid-defective strains of Bacillus subtilis. Appl Microbiol Biotechnol 97, 3721. https://doi.org/10.1007/s00253-012-4200-3 (2013)

46. Han, W. W., Shen, S. H., Tai, P. D. Proteome analysis of inhibitory effect of Gadolinium on Sinorhizobium Fredii J. Chin Rare Earth Soc 24, 623-627. https://doi.org/10.3321/j.issn:1000-4343.2006.05.020 (2006)

47.Han, W. W. Proteomic study on biological effects of rare earth elements. Dissertation for Master Degree of Institute of Botany, Chinese Academy of Sciences of China (2006) (in Chinese)

48.Chai, R. J., Wang, Y. L. Effect of REE on Growth of Bacteria and Fluorescence spectrum of DNA. Spectrosc Spect Anal. 33, 1829-1833 https://doi.org/10.3964/j.issn.1000-0593(2013)07-1829-05 (2013) (in Chinese)

49. Duan G. L. Cui, H. L., Yang, Y. P., et al. Interactions among soil biota and their applications in synergistic bioremediation of heavy-metal contaminated soils. Chin J Biotechnol. 36, 455-470 https://doi.org/10.13345/j.cjb.190598 (2020) (in Chinese)

50.Li, G. C., Zhang, S. Y., Xiao, W., Long, Z. Y. Zhang, N. M. Research progress on Endophytes in Rice.Chin Agricul Sci Bull 31,157-162 https://doi.org/cnki:sun:zntb.0.2015-12-026 (2015) (in Chinese)

51.Feng, Y., Shen, D., Song, W. Rice endophyte Pantoea agglomerans YS19 promotes host plant growth and affects allocations of host photosynthates. $J$ Appl Microbiol 100, 938-945. https://doi.org/10.1111/j.1365-2672.2006.02843.x (2006)

52.Haney, C. H., Samuel, B. S., Bush, J., Ausubel, F. M. Associations with rhizosphere bacteria can conferan adaptive advantage to plants. Nat Plants, l, 15051. https://doi.org/10.1038/nplants.2015.51 (2015)

53.Liu, Y. X., Zhang, Q. W., Zhou, M., et al. Insecticidal activity of Bacillus thuringiensis expressed in endophytic bacteria of rice. Chin J Agric Biotechol, 5,188-193. (1997) (in Chinese)

54.Yang, X. Y., Liu, Z. W., Hu, F. J., et al. Soil rare earth element and Nitride pollution on plant growth and physiology. J Chin Soic Rare Earth 37,1-11 https://doi.org/10.11785/S1000-4343.20190101 (2019) (in Chinese)

55.Li J. Z., Li, Z. H., Liu, L. P. Research progress of Research progress of Ralstonia and Cuprophile. Int J Lab Med. 29, 437-439 https://doi.org/10.3969/j.issn.1673-4130.2008.05.020 (2008) (in Chinese)

56.Ramos, A.C., Melo, J., de Souza, S.B. et al. Inoculation with the endophytic bacterium Herbaspirillum seropedicae promotes growth, nutrient uptake and photosynthetic efficiency in rice. Planta, 252, 87 https://doi.org/10.1007/s00425-020-03496-x (2020)

57.Wang, N., Fang Q., Wu, D., Sun, Q. Y. Identification of two Herbaspirillum strains and its growth-promoting effect on Vetiveria zizanioides L. under coal gangue stress. Microbiol China. https://doi.org/10.13344/j.microbiol.china.201107 (2021) (in Chinese)

58.Liu, J. W., Liu, Y., Xu, T., Bu, Z. G., Liu, X. M., Zhu, Y. H. Advances and prospect of rice endophyte . Life Sci Res https://kns.cnki.net/kcms/detail/43.1266.Q.20201103.1719.006.html (2021) (in Chinese)

59.Hossain, M. T., Khan, A., Chung, E. J., Rashid, M. H., Chung, Y. R. Biological Control of Rice Bakanae by an Endophytic Bacillus oryzicola YC7007. Plant Pathol J. 32, 228-41 https://doi.org/10.5423/PPJ.OA.10.2015.0218 (2016)

60.Raheem, S., Abdul, L. K., Liaqat, A., Saqib, B., Muhammad, I., Kyung-Sook, C., et al.Characterization of New Bioactive Enzyme Inhibitors from Endophytic Bacillus amyloliquefaciens RWL-1. Molecules. 23, 114 https://doi.org/10.3390/molecules23010114 (2018) 
61.Fen A. J. Microbial communities and genomics of an ammonia nitrogen-degrading Bacterium in the tailings of rare-earth-element mines in Southern Jiangxi, China. Dissertation for Doctor Degree Sun Yat-sen University of China (2017) (in Chinese)

62.Gracioso, L. H. Analysis of copper response in Acinetobacter sp. by comparative proteomics. Metallomics. 11, 949-958 https://doi.org/10.1039/C8MT00365C (2019)

63.Wu, Z. Z., Su, J. F., Ali, A., Hu, X. F., Wang, Z. Study on the simultaneous removal of fluoride, heavy metals and nitrate by calcium precipitating strain Acinetobacter sp. H12. J Hazard Mater 405, 124255 https://doi.org/10.1016/j.jhazmat.2020.124255 (2021)

64.Li, C. G. The 28th International Mineral Processing Congress and the Thesis Topic. Multipurpose Utilization of Mineral Resources, 3,123-128. https://doi.org/10.3969/j.issn.1000-6532.2017.03.026 (2017) (in Chinese).

65.Wu, K., Luo, J. P., Li, J. X. An, Q. L., Yang, X. E., Liang, Y. C., Li, T. Q. Endophytic bacterium Buttiauxella sp. SaSR13 improves plant growth and cadmium accumulation of hyperaccumulator Sedum alfredii. Environ Sci Pollut R 125, 21844-21854 https://doi.org/10.1007/s11356-018-2322-6 (2018)

66.He, F. G., Ren, Z. H., Mi, X., J., Cui, J. Z. Advances in degradation of petroleum pollutants by Comamonas testosteroni. Chin Bull Life Sci 25,106-112 http://www.cnki.net/kcms/detail/31.1600.Q.201210 24.1541.008.html (2013) (in Chinese)

67.Zhong, G. M. Effects of chamaecrista rotundifolia on dynamic changes of soil soluble nitrogen and bacterial communities in Orchard red earth. Dissertation for Doctor Degree Fujian agriculture and Forestry University of China (2019) (in Chinese)

68.Masum, M.M.I., Liu, L., Yang, M., Hossain, M. M., Siddiqa, M. M., Supty, M. E., Ogunyemi, S. O., Hossain, A., An, Q., Li, B. Halotolerant bacteria belonging to operational group Bacillus amyloliquefaciens in biocontrol of the rice brown stripe pathogen Acidovorax oryzae. $J$ Appl Microbiol 125, 1852-1867 https://doi.org/10.1111/jam.14088 (2018)

69.Maria, R., Sumera, Y., Mahreen, Y., Claudia, B., Mika, T., Thomas, R.The wheat growth-promoting traits of Ochrobactrum and Pantoea species, responsible for solubilization of different $\mathrm{P}$ sources, are ensured by genes encoding enzymes of multiple P-releasing pathways. Microbiol Res 246, 126703 https://doi.org/10.1016/j.micres.2021.126703 (2021)

70.Pandit, S. G., Krishna, P., Dhale, M. A., et al. Bactericidal effects of exiguobacterium sp GM010 pigment against food-borne pathogens. Front Sustain Food Syst 4,1-9. https://doi.org/10.3389/fsufs.2020.00142 (2020)

71.Kim, J.Y., Kim, H. S., Lee, S. M., Park, H. J., Lee, S. H., Jang, J. S., Lee, M. H. Plant growth promoting and disease controlling activities of pseudomonas geniculata ANG3, Exiguobacterium acetylicum ANG40 and Burkholderia stabilis ANG51 Isolated from Soil. Microbiol Biotechnol Lett 48, 38-47 https://doi.org/10.4014/mbl.1906.06002 (2020)

72.Devi, P. B., Kavitake, D., Jayamanohar, J., Shetty, P. H. Preferential growth stimulation of probiotic bacteria by galactan exopolysaccharide from Weissella confusa KR780676. Food Res Int 143, 110333 https://doi.org/10.1016/j.foodres.2021.110333 (2021)

73.Shi, L.D., Chen, Y.S., Du, J.J., Hu, Y. Q., Shapleigh, J. P., Zhao, H. P. Metagenomic evidence for a methylocystis species capable of bioremediation of diverse heavy metals. Front microbiol 9, 3297 https://doi.org/10.3389/fmicb.2018.03297 (2018)

74.Zhang W. J. Antimicrobial activity and antimicrobial components from fermentation broth of streptomyces djakartensis NW35. Dissertation for Doctor Degree Northwest A \& F University of China (2013) (in Chinese)

75.Sperfeld, M., Rauschenbach, C., Diekert, G., Studenik, S. Microbial community of a gasworks aquifer and identification of nitrate_reducing Azoarcus and Georgfuchsia as key players in BTEX degradation. Water Res 132, 146-157 https://doi.org/10.1016/j.watres.2017.12.040 (2018) 
76.Khan, A. L., Ullah, I., Hussain, J., Kang, S. M., Al-Harrasi, A., Al-Rawahi, A., et al.Regulations of essential amino acids and proteomics of bacterial endophytes S phingomonas sp. Lk11 during cadmium uptake. Environ Toxicol. 31, 887-896 https://doi.org/10.1002/tox.22100, (2016)

77.Lundberg, D.S., Lebeis, S.L., Paredes, S.H., et al. Defining the core Arabidopsis thaliana root microbiome. Nature,488, 86-90. https://doi.org/10.1038/nature11237 (2012)

78.Bulgarelli, D., Rott, M., Schlaeppi, K.,et al. Revealing structure and assembly cues for Arabidopsis root-inhabiting bacterial microbiota.Nature, 488,91-95 https://doi.org/10.1038/nature11336 (2012)

79. Carini, P., Marsden, P.J., Leff, J.W., Morgan, E.E., Strickland, M.S., et al. Relic DNA is abundant in soiland obscures estimates of soil microbial diversity, Nat Microbiol. 2, 16242. https://doi.org/10.1038/ nmicrobiol.

$2016.242 \quad$ (2016)

\section{Author contributions:}

X.Z.Z. performed all the experiments with the help of S.L.J., Z.J.H, H.H.P., Y.J.B. and Y.H., X.Z.Z. wrote the manuscript. S.L.J. and Z.J. H. made the data processing and analysis. X.Z.Z.. prepared Figs. 1-6. S.L.J.prepared Figs. 7-9. All the authors reviewed the manuscript and approved the version to be published.

\section{Competing interests:}

The authors declare no competing interests.

\section{Additional information}

Correspondence and requests for materials should be addressed to S.J. 